\title{
A CONSTITUTIONAL REMEDY FOR THE HIGH COST OF BROADCAST AND NEWSPAPER ADVERTISING IN POLITICAL CAMPAIGNS
}

The high cost of running for elective office may be one of the most undemocratic and is certainly one of the most disturbing features of the American electoral system. ${ }^{\mathrm{I}}$ The best financed candidate often has the most ready access to quick transportation, to well-staffed and well-stocked campaign headquarters, and to saturation advertising in both the printed and electronic media. Donations and loans from large campaign contributors to fund these efforts may or may not result in political favors, but in any event, they tend to raise public suspicions that big government and big money are closely intertwined. ${ }^{2}$

Congress has recently taken steps to stem the spiraling rise of campaign spending. Beginning in 1976, presidential candidates in the general election may receive public financing for their campaigns under the Revenue Act of 1971 from a fund created by taxpayers who check off $\$ 1$ contributions on their tax returns. ${ }^{3}$ Beneficiaries of public financing will be eligible for funding equal to 15 cents times the number of voting age persons in the country subject to a repayment penalty for any expenditure over that amount. ${ }^{4}$ In addition, the Federal Election Campaign Act of $1971^{5}$ imposes ceilings on the amount of money that candidates for federal offices and their supporters may spend on media advertising ${ }^{6}$ and requires detailed disclosure of the source of campaign funds. ${ }^{7}$

1. See text accompanying notes $98-112$ infra for statistics documenting the enormity of campaign costs, both nationally and locally.

2. John Gardner, former Secretary of Health, Education, and Welfare and current chairman of Common Cause, the citizen' lobby, which has staunchly supported campaign reform, has said:

Most of the political process has become-behind the scenes-a vast game of barter and purchase involving campaign contributions, appointnents to high office, business favors, favorable legal decisions. ... It is a game that is going on at every level of government. And it is paid for, ultimately, by the American taxpayer.

NewsweER, Dec. 13, 1971, at 24.

3. Revenue Act of Dec. 10, 1971, Pub. L. No. 92-178, $\S 801,85$ Stat. 497. See text accompanying notes 127-32 infra.

4. Id. $\$ \S 9004(\mathrm{a})(1), 9007(\mathrm{~b})$. The voting age population is determined as of June 1 of the year preceding the election. Id. $\S 9004$ (a)(1).

5. Pub. L. No. 92-225, 86 Stat. 3 (Feb. 7, 1972).

6. Candidates and their supporters may spend the greater of 10 cents per voting age person or $\$ 50,000$ on radio, television, newspaper, magazime, billboard, and telephone advertising. Id. $\S \S 102,104(\mathrm{a})(1)(\mathrm{A})$. No more than 60 percent of that amount may be spent on the electromic inedia. Id. $\S 104(\mathrm{a})(1)(\mathrm{B})$.

7. Id. $\$ 304$. 
Although these are commendable reforms, they fall far short of solving the problem. The controls that the Election Campaign Act places on campaign expenditures, for example, are not all rigorous. ${ }^{8}$ Moreover, the Act leaves state and local elections basically unregulated. ${ }^{9}$ There are also serious questions regarding the constitutionality of these measures. ${ }^{10}$ Most significant, however, is that except for presidential elections, the two Acts fail to deal with the heart of the problem: As long as political campaigns are financed entirely by private sources, basic inequities between candidates on the basis of wealth and ability to attract substantial financial support will remain. This Comment examines the feasibility of court action to remedy at least one consequence of this problem-that the best financed candidates have the easiest access to radio, television, and newspaper advertising.

The Supreme Court took a tentative, albeit indirect, step into the area of burgeoning campaign costs in Bullock $v$. Carter $^{11}$ when it struck down a Texas filing fee scheme that required candidates for public office to pay fees ranging from $\$ 50$ to $\$ 8,900$ for the privilege of getting their names printed on the primary ballot. The Court held that burdens on the right to vote that fall more heavily on not only poor voters but also poor candidates violate the equal protection clause of the fourteenth amendment. ${ }^{12}$ This Comment rehies on Bullock as cornerstone support for the proposition that the equal protection clause forbids broadcast licensees and newspaper publishers from discriminating in the allocation of campaigu advertising on the basis of ability to pay.

\section{I}

\section{Filing Fee ReQuirements}

\section{A. The Judicial Background}

Many states require the payment of a filing fee before permitting

8. See text accompanying notes 124-25 infra.

9. Section 104(d)(1)-(4) of the Federal Election Campaign Act [Pub. L. No. 92-225, 86 Stat. 3 (Feb. 7, 1972)] declares simply that if a state requires its elections to conform with the provisions of the Federal Election Campaign Act, a broadcast licensee may sell no advertising time for state or local elections without a written statement from the candidate that the expenditure will not exceed his spending ceiling. In addition, section 103 amended section 315(b) of the Communications Act of 1934 [47 U.S.C. $\$ 315(b)(1970)$ ] to require that the cost per unit of time charged all public office candidates, whether federal, state, or local not exceed the charge made for comparable use of time for other purposes. The Act does not, however, limit the amount of money that candidates for state and local offices may spend on media advertising.

10. See text accompanying notes 116-23 infra.

11. 405 U.S. 134 (1972).

12. Id. at 144, 149. 
a candidate's name to be listed on the ballot. ${ }^{13}$ Traditionally courts sustained such fees if found to be reasonable when measured against state constitutional provisions guaranteeing free and equal elections ${ }^{14}$ or prohibiting voter and candidate property ownership requirements. ${ }^{15}$ The size of the fee was often critical; when a fee was found not to bear a reasonable relationship to the cost of candidate registration it was struck down, ${ }^{16}$ but the courts were often divided as to what was a reasonable relationship. ${ }^{17} \mathrm{~A}$ few courts found filing fee requirements unreasonable because they impaired the voters' right to choose their candidates freely ${ }^{18}$ or because they placed upon voters the burden of paying their candidate's filing fee if he could not afford it. ${ }^{19}$ Some courts, on the other hand, found a state's fee reasonable as a method to defray a portion of the election costs on the ground that those seeking the benefit of a state function could be expected to bear a share of the expenses. ${ }^{20}$ Other courts sustained fees purportedly designed to limit the size of the ballot on the ground that worthy candidates would have no difficulty paying the required amount. ${ }^{21}$

13. See Comment, The Constitutionality of Qualifying Fees for Political Candidates, 120 U. PA. L. REv. 109, 136-42 (1971) for a detailed listing of the requirements of each state. See also Note, The Constitutionality of Candidate Filing Fees, 70 Mich. L. REv. 558, 558-59, which traces the development of filing fee legislation im the United States.

14. Annot., 89 A.L.R.2d 867 (1963).

15. See, e.g., Socialist Party v. Uhl, 155 Cal. 776, 789, 103 P. 181, 186-87 (1909).

16. E.g., People ex rel. Breckon v. Board of Election Comm'rs, 221 Ill. 9, 21, 77 N.E. 321, 324 (1906); Kelso v. Cook, 184 Ind. 173, 201, 110 N.E. 987, 996 (1916); Johnson v. Grand Forks County, 16 N.D. 363, 375, 113 N.W. 1071, 1075-76 (1907); Ballinger v. McLaughlin, 22 S.D. 206, 209, 116 N.W. 70, 71 (1908).

17. People ex rel. Breckon v. Board of Election Comm'rs, 221 Ill. 9, 77 N.E. 321 (1906) ( $\$ 100$ filing fee unreasonably high and arbitrary); State ex rel. Riggle v. Brodigan, 37 Nev. 492, 143 P. 238 (1914) ( $\$ 100$ fee reasonable); Kean v. Lawrence, 30 Pa. D. \& C. 235 (12th Dist. 1937) (fees ranging from 50 cents to $\$ 50$ reasonable). See also Socialist Party v. Uhl, 155 Cal. 776, 103 P. 181 (1909); Kenneweg v. County Comm'rs, 102 Md. 119, 62 A. 249 (1905); State ex rel. Thompson v. Scott, 99 Minn. 145, 108 N.W. 828 (1906); State ex rel. Zent v. Nichols, 50 Wash. 508, 97 P. 728 (1908).

18. State ex rel. Adair v. Drexel, 74 Neb. 776, 793, 105 N.W. 174, 180 (1905).

19. Jolnnson v. Grand Forks County, 16 N.D. 363, 370, 113 N.W. 1071, 1073 (1907).

20. Socialist Party v. Uhl, 155 Cal. 776, 789-90, 103 P. 181, 187 (1909); Munsel v. Hennegan, 182 Md. 15, 24, 31 A.2d 640, 645 (1943); Riter v. Douglass, 32 Nev. 400, 437-38, 109 P. 444, 456 (1910); State ex rel. Zent v. Nichols, 50 Wash. 508, 520, 97 P. 728, 730 (1908).

21. Socialist Party v. Uhl, 155 Cal. 776, 790, 103 P. 181, 187 (1909). See also Bodner v. Gray, 129 So. 2d 419, 421 (Fla. 1961); State ex rel. Thompson v. Scott, 99 Minn. 145, 148, 108 N.W. 828, 830 (1906); McLean v. Durham County Bd. of Elections, 222 N.C. 6, 10, 21 S.E.2d 842, 845 (1942). Contra, Kelso v. Cook, 184 Ind. 173, 202, 110 N.E. 987, 996 (1916) (minority parties serve a valuable public function and sliould not be excluded from the ballot); Johnson v. Grand Forks County, 16 N.D. $363,372,113$ N.W. 1071, 1074 (1907) (restricting the size of the ballot is 


\section{B. The Modern Approach}

An evaluation only of the reasonableness of a filing fee statute is now inadequate, however, in light of the Supreme Court's more expansive interpretation of the equal protection clause over the last decade. $^{22}$ Two standards are now employed. The traditional test is whether the challenged state action, though discriminatory, bears a rational relationship to a legitimate state policy. ${ }^{23}$ In cases involving "suspect classifications"24 or bearing upon "fundamental interests" ${ }^{25}$ or constitutional rights, ${ }^{28}$ however, the Court has imposed a variety of stricter tests. In some cases, a statute has been invalidated for being invidiously discriminatory. ${ }^{27}$ In other cases, the Court has required a state to justify its discriminatory practice by showing that: (1) the statute is precisely tailored to achieve the articulated state goal; ${ }^{28}(2)$ there are no reasonable alternatives to which the state may constitutionally resort to achieve its interests; ${ }^{20}$ or (3) the statute or practice is necessary to the achievement of a compellimg state interest. ${ }^{30}$

During the $2 \frac{1}{2}$ years preceding Bullock $v$. Carter, ${ }^{31} 11$ federal dis-

beyond the power of the legislature since to do so would discourage minority party candidates).

22. See generally, Developments in the Law-Equal Protection, 82 HARv. L. Rev. 1065 (1969). It has long been established that although states may regulate their own elections, they may not do so in a manner inconsistent with the Federal Constitution. Pope v. Williams, 193 U.S. 621, 632-34 (1904).

23. E.g., McGowan v. Maryland, 366 U.S. 420, 425 (1961) (statute permitting some products to be sold on Sunday but not others does not violate the equal protection clause under a test of rationality).

24. Graham v. Richardson, 403 U.S. 365 (1971) (alienage); Tate v. Short, 401 U.S. 395 (1971) (violation of equal protection to jail a person for inability to pay a fine unless no other alternatives are available); Harper v. Virginia Bd. of Elections, 383 U.S. 663 (1966) (right to vote denied on the basis of wealth); McLaughlin v. Florida, 379 U.S. 184 (1964) (race); Douglas v. California, 372 U.S. 353 (1963) (right to counsel on criminal appeal denied on basis of wealth); Griffin v. Illinois, 351 U.S. 12 (1956) (right to transcript on criminal appeal denied on the basis of wealth).

25. Dunn v. Blunistein, 405 U.S. 330 (1972) (right to vote); Reynolds v. Sims, 377 U.S. 533 (1964) (right to vote); cf. Skinner v. Oklahonna, 316 U.S. 535 (1942) (right to procreate).

26. Dunn v. Blumstein, 405 U.S. 330 (1972) (right of interstate travel); Shapiro v. Thompson, 394 U.S. 618 (1969) (right of interstate travel); Williams v. Rhodes, 393 U.S. 23 (1968) (first amendment freedont of association).

27. See, e.g., Harper v. Virginia Bd. of Elections, 383 U.S. 663, 666-67 (1966); Carrington v. Rash, 380 U.S. 89, 96 (1965).

28. See, e.g., Kramer v. Union Free School Dist., 395 U.S. 621, 632 (1969) (voting in school board election may not be limited to owners and lessors of real property and parents of schoolchildren).

29. See, e.g., Tate v. Short, 401 U.S. 395, 399 (1971) (state may not imprison indigent for failure to pay a fine).

30. See, e.g., Dunn v. Blunistein, 405 U.S. 330, 335 (1972); Shapiro v. Thompson, 394 U.S. 618, 634 (1969); Williams v. Rhodes, 393 U.S. 23, 31 (1968).

31. 405 U.S. 134 (1972). 
trict courts ruled on the constitutionality of filing fees; ${ }^{32}$ eight used the compelling interest test, all but one invalidating the challenged fee. ${ }^{33}$ Three courts employed the traditional test of rationality. ${ }^{34}$

\section{The Compelling Interest Test}

The federal district courts that invalidated filing fees based their application of the compelling interest equal protection test on one or more of three rationales: (1) discrimination against a suspect class, (2) denial of a constitutional right, and (3) denial of a fundamental interest.

The first approach, based upon the Supreme Court's disapproval of a $\$ 1.50$ poll tax in Harper v. Virginia Board of Elections, ${ }^{35}$ is grounded on the notion that classifications based on wealth are suspect. ${ }^{36}$ Jenness $v$. Little ${ }^{37}$ relied principally on this line of reasoning to invalidate Atlanta's filing fee schedule, which ranged froin $\$ 400$ for school board member to $\$ 1,000$ for mayor, arguing that "the length of one's pocketbook alone may [not] be made the yardstick as to whether one's naine appears or does not appear on the ballot." 38

The second approach, unlike the other two, focuses upon the rights of voters instead of the rights of candidates. The argument is that a voter who is denied the opportunity to support the candidate of his choice is also being denied his first amendment right of political

32. Socialist Workers Party v. Welch, 334 F. Supp. 179 (S.D. Tex. 1971); Duncantell v. City of Houston, 333 F. Supp. 973 (S.D. Tex. 1971); Wong v. Mihaly, 332 F. Supp. 165 (N.D. Cal. 1971); Spillers v. Slaughter, 325 F. Supp. 550 (M.D. Fla.), vacated sub nom., Pope v. Haimowitz, 404 U.S. 806 (1971); Carter v. Dies, 321 F. Supp. 1358 (N.D. Tex. 1970), aff'd sub nom., Bullock v. Carter, 405 U.S. 134 (1972); Thomas v. Mims, 317 F. Supp. 179 (S.D. Ala. 1970); Fowler v. Adams, 315 F. Supp. 592 (M.D. Fla. 1970), appeal dismissed, 400 U.S. 986 (1971); Georgia Socialist Workers Party v. Forston, 315 F. Supp. 1035 (N.D. Ga. 1970), aff'd on other grounds sub nom., Jenness v. Forston, 403 U.S. 431 (1971); Wetherington v. Adams, 309 F. Supp. 318 (N.D. Fla. 1970); Haag v. State, No. 70 426-R (C.D. Cal., Mar. 18, 1970); Jenness v. Little, 306 F. Supp. 925 (N.D. Ga. 1969), appeal dismissed as moot sub nom., Matthews v. Little, 397 U.S. 94 (1970).

33. The cases invalidating fees were Welch, Duncantell, Wong, Carter, Forston, Thomas and Jenness. Spillers upheld the fee. See note 32 supra.

34. The cases were Fowler, Wetherington, and Haag. See note 32 supra.

35. 383 U.S. 663 (1966). The opinion in Harper has been cliaracterized as a "sympliony of holdmgs." Michelman, On Protecting the Poor Through the Fourteenth Amendment, 83 HARv. L. REv. 7, 25 (1969).

36. See Note, Discrimination Against the Poor and the 14th Amendment, 81 HARv. L. REv. 435 (1967).

37. 306 F. Supp. 925 (N.D. Ga. 1969). Other cases employing suspect classification analysis were Socialist Workers Party v. Weich, 334 F. Supp. 179, 181-83 (S.D. Tex. 1971); Wong v. Mihaly, 332 F. Supp. 165, 167-68 (N.D. Cal. 1971); Georgia Sociakst Workers Party v. Forston, 315 F. Supp. 1035, 1041 (N.D. Ga. 1970), aff'd on other grounds sub nom., Jenness v. Forston, 403 U.S. 431 (1971).

38. 306 F. Supp. at 929. 
association, recognized in Williams $v$. Rhodes, ${ }^{39}$ where Ohio's intricate election laws made it difficult for nore than two parties to get on the ballot. Citing Williams, the three-judge Texas federal district court that heard the original arguments in Bullock v. Carter ${ }^{40}$ held that the constitutional right of political association was also abridged by a Texas filing fee scheme that not only required filing fees for primary elections ranging from $\$ 50$ upwards but also enabled county committees to levy an assessment on each candidate, often reaching into the thousands of dollars, for the cost of running the election. ${ }^{41}$

The third approach in the lower courts' treatment of filing fees focuses on the rights of candidates and declares that running for office is a corollary to the right to vote and demands similarly that a compelling state interest be served as a condition to its abridgment. ${ }^{42}$ Although the Constitution does not expressly confer a right to vote in state elections, ${ }^{43}$ courts have consistently deemed it a fundamental interest that can only be abridged in very special circumstances. ${ }^{44}$ Prior to Bullock, the Supreme Court had yet to pass on whether the right to run for office should be accorded the same constitutional respect as the right to vote; ${ }^{45}$ nevertheless, four of the lower federal courts so held. ${ }^{4 b}$

The only modern cases to hold that the imposition of a qualifying fee necd only be grounded on a rational state interest are Wetherington v. Adams, ${ }^{47}$ Fowler v. Adams, ${ }^{48}$ and Haag v. State. ${ }^{49}$ The courts in Wetherington and Fowler sought to escape the compelling interest test on two grounds: first, there was no discrimination against

39. 393 U.S. 23, 30 (1968).

40. Sub nom. Carter v. Dies, 321 F. Supp. 1358 (N.D. Tex. 1970).

41. Id. at 1362.

42. Wong v. Mihaly, 332 F. Supp. 165, 167 (N.D. Cal. 1971); Thomas v. Mims, 317 F. Supp. 179, 181 (S.D. Ala. 1970); Socialist Workers Party v. Welch, 334 F. Supp. 179, 183 (S.D. Tex. 1971); Duncantell v. City of Houston, 333 F. Supp. 973, 976 (S.D. Tex. 1971). It should be noted that Wong and Welch based their holdings on both suspect classification and fundamental interest rationales.

43. See Harper v. Virginia Bd. of Elections, 383 U.S. 663, 665 (1966).

44. Reynolds v. Sims, 377 U.S. 533, $561-62$ (1964); Yick Wo v. Hopkins, 118 U.S. 356, 370 (1886). See also Kramer v. Union School Dist., 395 U.S. 621 (1969); Harper v. Virginia Bd. of Elections, 383 U.S. 663 (1966); see generally Developments in the Law-Equal Protection, 82 HARv. L. Rev. 1065, 1127-37 (1969).

45. In Turner v. Fouche, 396 U.S. 346, 364 (1970), the Court reviewed a Georgia law restricting membership on school boards to freeholders. The Court found it unnecessary, however, to decide if the right to hold office was a fundamental interest, since the requirenient was wholly irrelevant to the achievement of a valid state objective and thns violated traditional notions of equal protection.

46. See cases cited note 42 supra.

47. 309 F. Supp. 318 (N.D. Fla. 1970).

48. 315 F. Supp. 592 (M.D. Fla. 1970), appeal dismissed, 400 U.S. 986 (1971).

49. Civ. No. 70-426-R (C.D. Cal., March 18, 1970), cited in Choate v. Brown, Civ. No. C-72-380 (N.D. Cal., March 9, 1972) (three-judge court). 
the poor since those who could not afford the filing fee could always conduct a write-in campaign; ${ }^{50}$ second, there was no abridgment of a fundamental interest since the rights of voters were not involved. ${ }^{51}$ The court in Haag contended that indigent candidates were not discriminated against since under California law they could escape the filing fee requirement by running as the nominee of their party, rather than as an independent candidate. It is highly questionable whether these three cases are any longer viable in view of the Supreme Court's decision in Bullock v. Carter $^{52}$

\section{Finding a Compelling State Interest}

In attempting to meet their burden of showing that the challenged requirement was necessary to a compelling interest, states have put forth three arguments: first, the fees help defray the cost of conducting elections; second, fees limit the size of the ballot; and third, fees help insure agamst frivolous candidacies.

The revenue interest has been uniformly rejected. If the fee is small, the state collects enough to cover only a fraction of its expenses. $^{53}$ Such a benefit falls far short of being necessary to pay for the election not only because of its small size but also because the state has and uses other sources to fund elections that do not impinge upon constitutional rights. ${ }^{54}$

On the other hand, if the fee is large enough to compensate the state or the political party for its election costs, then it may violate even traditional equal protection notions of reasonableness. ${ }^{55}$ And, as

50. 309 F. Supp. at $322 ; 315$ F. Supp. at 595.

51. 309 F. Supp. at $322 ; 315$ F. Supp. at 596 .

52. The Bullock Court specifically rejected the rationale relied upon in Haag. 405 U.S. 134, 146-47 (1972). The schemes passed upon in Wetherington and Fowler, however, are different from the Texas scheme reviewed in Bullock since they permitted write-in candidacies and Texas did not. It is doubtful whether this distinction is significant, though, since Bullock described the circumstances in which a filing fee might be permissible yet made no mention of a write-in alternative. See text accompanying notes $94-95$ infra.

53. The San Francisco fee challenged in Wong v. Mihaly, 332 F. Supp. 165 (N.D. Cal. 1971), for example, was 2 percent of the salary of the office sought [City aNd CounTy of SAN Francisco CharTer $\$ 175$ (1968)] and ranged from $\$ 192$ for a seat on the Board of Supervisors to $\$ 828.99$ for mayor. The $1971-72$ city budget allocated $\$ 1,285,108$ for election expenditures $[\$ 1,094,491$, City and County of San Francisco, Final Budget of Expenditures, at 390 (line 18); $\$ 147,450$, City and County of San Francisco, Supplemental Appropriations Ordimance, Resolution No. 198 (1971-72); $\$ 43,167, I d$. Resolution No. 263]; yet the city anticipated only $\$ 5,000$ revenue from filing fees, less than one-half of 1 percent of expected election costs [City and County of San Francisco, Revenue Budget, County Filing Fees, Revenue Account No. 7036].

54. Carter v. Dies, 321 F. Supp. 1358, 1361-62 (N.D. Tex. 1970), affd sub nom., Bullock v. Carter, 405 U.S. 134 (1972).

55. See cases cited note 17 supra. 
in the case of smaller fees, the ability of the state to pay for elections with other public funds refutes any claim that filing fees are an indispensable revenue raising device. ${ }^{56}$

An interest in limiting the size of the ballot lias been stressed when voting machines are used, on the ground that there is a limited number of voting levers. ${ }^{57}$ Also, the federal district court in Spillers $v$. Slaughter, ${ }^{58}$ the only court to upliold filing fees under the strict equal protection test, deemed the ballot regulation interest compelling simce a small ballot increases the likelihood of finding a majority choice without excessive runoffs. ${ }^{59}$ Once again, lowever, the state could seek to achieve the same objective in less restrictive ways. ${ }^{60}$ For example, requiring a candidate to submit a nominating petition signed by a significant percentage of the electorate would probably limit the size of the ballot as effectively as a filing fee requirement; in fact, such an approach has been uplield against constitutional challenge by a unanimous Supreme Court. ${ }^{01}$

The state imterest in discouraging frivolous candidacies is based on the argument that inability to pay a filing fee suggests that a candidate cannot attract financial support and therefore is not a serious contender. ${ }^{62}$ Thus, the state not only seeks to make a political judgment that has been traditionally reserved for the voters but also pronounces a state policy of discrimination toward the poor and toward candidates supported by the poor. Surely, a permissible state interest cannot be justified solely because it furthers the very discrimina-

56. The uniform rejection of the importance of a financial interest by the lower courts seemed appropriate in light of the Supreme Court's apparent lack of sympathy toward arguments warning of dangers to the fisc when important individual rights were at stake. Shapiro v. Thompson, 394 U.S. 618, 633 (1969) (preserving statc funds is not a compelling interest that warrants abridgment of the right of interstatc travel by denying new residents welfare assistance); Sherbert v. Verner, 374 U.S. 398, 407 (1963) (preserving a state's unemployment compensation fund is not sufficiently important to warrant infringements of first amendment freedom of religion rights); Follett v. McCormick, 321 U.S. 573, 575 (1944) and Mnrdock v. Pennsylvania, 319 U.S. 105, 113-14 (1943) (city's revenue interest is insufficient reason to impose a peddler's tax that harms religious colporteurs). In Bnllock v. Carter, 405 U.S. at 147, however, the Court measured the state's financial interest against a standard of legitimacy and found it valid. See text accompanying notes 82-84 infra.

57. Wetherington v. Adams, 309 F. Supp. 318, 321 (N.D. Fla. 1970).

58. 325 F. Supp. 550 (M.D. Fla.), vacated sub nom., Pope v. Haimowitz, 404 U.S. 806 (1971).

59. Id. at 553 .

60. Wong v. Mihaly, 332 F. Supp. 165, 168 (N.D. Cal. 1971); Duncantell v. City of Houston, 333 F. Supp. 973, 976 (S.D. Tex. 1971); Socialist Workers Party v. Welch, 334 F. Supp. 179, 183-84 (S.D. Tex. 1971); Thomas v. Mims, 317 F. Supp. 179, 182 (S.D. Ala. 1970).

61. Jenness v. Forston, 403 U.S. 431 (1971).

62. See Wetherington v. Adams, 309 F. Supp. 318, 321 (N.D. Fla. 1970). 
tion that is being challenged. Although the poor may have little chance of winning, the state itself should not be responsible for making them less able to try. ${ }^{63}$

The Supreme Court, therefore, considered Bullock v. Carter at a time when no fewer than 11 federal district courts had passed upon the constitutionality of filing fees in a little less than $2 \frac{1}{2}$ years. ${ }^{64}$ The courts had employed a variety of theories to weigh the validity of filing fees; they had come to different conclusions on the importance of the various state interests claimed; and they had presented varying viewpoints on when a filing fee should be upheld. In Wong v. Mihaly, ${ }^{65}$ for example, the court stipulated that the City of San Francisco could continue to assess a filing fee as long as the fees were waived for persons who attested that they were unable to pay. ${ }^{66}$ Alternatively, six courts suggested that if candidates are offered the option of paying a fee or submitting a petition of supporting signatures, the constitutional defect might be cured. ${ }^{67}$ Finally, one court upheld a fee on the ground that the indigent plaintiff might still seei the nomination of his party and, if successful, be exempted by statute from paying the required fee. ${ }^{88}$ Thus, a patchwork of lower court approaches to the problem of candidate filing fees stood to be considered when the Supreme Court rendered its decision in Bullock v. Carter.

\section{Bullock v. Carter $^{69}$}

Texas employed an elaborate filing fee scheme for primary elections whereby candidates seeking nomination for state and federal office had to pay fixed fees ranging from $\$ 50$ to $\$ 1,000$ depending upon the office sought and, in the case of candidates for the state legislature, the size of the population represented. ${ }^{70}$ Candidates for

63. Thomas v. Mims, 317 F. Supp. 179, 182 (S.D. Ala. 1970).

64. The first of the 11 filing fee cases, Jenness v. Little, 306 F. Supp. 925 (N.D. Ga. 1969), was decided September 5, 1969. Bullock was decided February $24,1972$.

65. 332 F. Supp. 165 (N.D. Cal. 1971).

66. Id. at 169.

67. Id. at 168; Socialist Workers Party v. Welch, 334 F. Supp. 179, 184-85 (S.D. Tex. 1971); Duncantell v. City of Houston, 333 F. Supp. 973, 976 (S.D. Tex. 1971); Thomas v. Mims, 317 F. Supp. 179, 182 (S.D. Ala. 1970); Georgia Socialist Workers Party v. Forston, 315 F. Supp. 1035, 1041 (N.D. Ga. 1970), aff'd on other grounds sub nom., Jenness v. Forston, 403 U.S. 431 (1971); Jenness v. Little, 306 F. Supp. 925, 929 (N.D. Ga. 1969), appeal dismissed as moot sub nom., Matthews v. Little, 397 U.S. 94 (1970).

68. Haag v. State, Civ. No. 70-426-R (C.D. Cal., March 18, 1970), cited in Choate v. Brown, Civ. No. C-72-380 (N.D. Cal., March 9, 1972) (three-judge court).

69. 405 U.S. 134 (1972).

70. Candidates for state representative paid fees ranging from $\$ 150$ to $\$ 600$. Tex. Election Code AnN. arts. 13.08a, 13.16(2) (1967). Candidates for the State 
local offices, on the other hand, paid fees assessed by county party committees to cover the cost of conducting the election. ${ }^{71}$ The Supreme Court unanimously ${ }^{72}$ struck down the entire Texas filing fee scheme as violative of the equal protection clause. The Court chose, however, to employ neither the rational basis test nor the compelling interest test. Rather, it declared that the challenged laws "must be 'closely scrutinized' and found reasonably necessary to the accomphshment of legitimate state objectives in order to pass constitutional inuster." 3 Precisely what significance should be attached to the Court's choice of language is unclear. The Court did not announce that it was establishing a new equal protection standard. Nevertheless, the words at face value seem to present a standard less stringent than the compelling interest test. The laws need not be necessary; they need only be reasonably necessary. And the interests put forth by the state need not be compelling; they need only be legitimate. As applied in Bullock, though, the variance in langnage was of no significance.

Texas argued two interests as justification for its filing fees: (1) regulating the size of the ballot; ${ }^{74}$ and (2) recovering the cost of conducting primary elections. ${ }^{75}$ The Court agreed that both these objectives were legitimate (whereas they may not have been coinpelling); however, the Court apparently interpreted the standard "reasonably necessary" not as a softening of the compelling interest standard, but rather as a dual test requiring both reasonableness-that is, precise tailoring to the articulated state goal-and necessity. ${ }^{70}$ Thus, in application the standard was much different from what its words would first suggest and was, in effect, virtually indistinguishable from the

Senate paid fees ranging from $\$ 1$ per county represented to a fixed fee of $\$ 1,000$. $I d$. arts. 13.08a, 13.16(1). Candidates for Governor and United States Senate paid a flat fee of $\$ 1,000$. Id. art. 13.15. Candidates for the State Board of Education had a fixed fee of $\$ 50$. Id. art. 13.08(4).

71. The party committee made an estimate of the total cost of the primary and apportioned the cost among the various candidates in a "just and equitable fashion." Id. art. 13.08. In large counties the fee could not exceed a fixed percentage of the annual salary of the office sought-10 percent for offices with 2-year terms and 15 percent for offices with 4-year terms. Id. art. 13.08a. In smaller counties, however, there were no percentage ceilings, and assessments of over $\$ 5,000$ were not unusual; candidates for at least one office had to pay an $\$ 8,900$ fee. Bullock v. Carter, 405 U.S. at 138 n.11.

72. Justices Powell and Rehnquist did not participate.

73. 405 U.S. at 144.

74. 405 U.S. at $144-45$.

75. Id. at 147.

76. After weighing the state's arguments, the Court concluded that "[a]ppellants have not demonstrated that their present filing fee scheme is a necessary or reasonable tool for regulating the ballot." Id. See also text accompanying notes 77-84 infra. 
compelling interest test that the Court apparently sought to avoid. For although some state objectives may be legitimate but not compelling, a law is rarely necessary in the sense that it accomphishes a state goal no other law could accomplish. And both the compelling interest test and Bullock require a statute to meet that exacting standard.

Under this demanding two-pronged test of reasonableness and necessity, both state interests failed. The Court recognized the state's interest in avoiding complicated and confusing election machinery and assuring a majority or strong plurality without runoffs. ${ }^{77}$ It concluded, lowever, that filing fees were "extraordinarily ill-fitted to that goal"78 since legitimate as well as frivolous candidates would suffer exclusion from the ballot. Moreover, the Court noted that there were other methods of excluding spurious candidates to limit the size of the ballot ${ }^{70}$-for example, by requiring nominating petitions as previously approved by the Court in Jenness $v$. Forston. ${ }^{80}$ Thus, the Court dismissed the ballot regulation interest for failure to meet either a standard of reasonableness or a standard of necessity. ${ }^{81}$

The Court in an earlier case had found that when balanced agamst constitutional rights, the state's interest in husbanding its resources was not compelling. ${ }^{82}$ Under a standard of legitimacy, however, the Bullock Court declared that the state's interest in reducing its expenditures was valid, ${ }^{83}$ but found that Texas had not shown that a filing fee was necessary to achieve that interest. Noting that the state financed general elections, the Court contended that primary elections were of nearly equal importance in deciding who was to govern and so did not warrant a different fimancing scheme. If one could be financed out of general funds so could the other, and a filing fee for primary elections was therefore not necessary. ${ }^{84}$

Because Bullock's holding that a filing fee must be reasonably necessary to a legitimate state interest appears to differ little, at least in the voting context, from the compelling interest test, the most realistic evaluation of the Court's choice of language may be that the opimion's author, Chief Justice Burger, simply dislikes the compelling interest test. In a dissent to Dunn $v$. Blumstein, ${ }^{85}$ decided shortly

77. Id. at 145 .

78. Id. at 146 .

79. Id. at $145-46$.

80. 403 U.S. 431 (1971). See text accompanying note 61 supra.

81. 405 U.S. at 147.

82. Shapiro v. Thompson, 394 U.S. 618, 633 (1969).

83. 405 U.S. at 147.

84. Id. at $148-49$.

85. 405 U.S. 330 (1972) (voter durational residency laws unconstitutionally inhibit right to vote and right to interstate travel). 
after Bullock, in which the majority applied the compelling interest test, the Chief Justice argued that the compelling interest test was too blunt since no statute had ever withstood its scrutiny. "Some lines must be drawn" when extending the right to vote, he noted, and "[t]o challenge such lines by the 'compelling state interest' standard is to condemn them all." ${ }^{26}$ Thus, it seems likely that Chief Justice Burger attempted, at least, to formulate a less stringent equal protection test for general use; and, im particular, he may have been seeking to make possible at least some sort of candidate filing fee scheme.

Indeed, the Court indicated that not all filing fee schemes were invalidated by its holding in Bullock and noted that a "reasonable" fee might be permissible. ${ }^{87}$ This language is in puzzling contrast to the Court's requirement that the Texas fee under review be both reasonable and necessary. Perhaps the Court is suggesting that a modest fee would not impermissibly burden the right to run for office and therefore would only be required to meet the easier rational basis test. The Court is not clear on this issue, though language throughout the opimion suggests what form a reasonable fee might take. For example, at one point the Court distinguished the Texas scheme from fees that most candidates could meet from their own funds or from modest contributions, thereby implying that a smaller fee might survive constitutional scrutiny. ${ }^{88}$ Such language is confusing since some filing fees under the Texas scheme were as small as $\$ 50$; nonetheless the Court invalidated the entire scheme without distinguishing between the sizes of the fees imposed.

Perhaps a more precise characterization of the type of fee the Court would consider reasonable would be one that accurately reflects the adıninistrative costs of processing the candidate's application for a place on the ballot. Although the Court did not explicitly sanction such an approach, it suggested in a footnote that such a fee would present a different case. ${ }^{80}$ Indeed, the first court to review a filing fee after Bullock seized upon this footnote as clarification of the Court's statement that it had no intention of casting doubt on the validity of reasonable fees. ${ }^{90}$

86. Id. at 363 .

87. 405 U.S. at 149 ,

88. Id. at 143.

89. Id. at 148 n.29.

90. Choate v. Brown, Civ. No. C-72-380 (N.D. Cal., March 9, 1972) (threejudge court):

[T]he Supreme Court indicates that when it is speaking of "reasonable" candidate filing fees, it has in mind inerely filing fees sufficient "to cover the cost of filing, that is, the cost of placing a particular document on the public record." 
The Court also suggested that a filing fee might be acceptable if there were reasonable alternative means of getting access to the ballot, ${ }^{91}$ citing with approval its decision in Jenness $v$. Forston, ${ }^{92}$ which held that requiring a nominating petition was a legitimate way for a state to limit the size of the ballot. The Court explicitly rejected as a reasonable alternative the opportunity to seek a spot on the general election ballot with a nominating petition, because this would require skipping the primary election and thus, abandoning party affiliation simply to avoid a filing fee. ${ }^{93}$

The Court did not decide whether a write-in provision or a pauper's affidavit alternative would be the sort of reasonable alternative that might inake the retention of a filing fee permissible. ${ }^{94}$ The lower courts that considered these alternatives, however, rejected a write-in provision as inadequate ${ }^{95}$ while declaring a pauper's affidavit option to be acceptable. ${ }^{96}$

Bullock represents a strong affirmation and a slight expansion of the Court's landmark decision in Harper v. Virginia Board of Elections $^{97}$ in holding that economic burdens that fall with unequal weight upon not only voters, but also candidates, will be subject to strict equal protection scrutiny and will be upheld only when sliown to be reasonably necessary to the accomplishment of a legitimate state objective. In liglit of Bullock, parts II and III of this Comment examine whether charging candidates a fee for the use of radio, television, and news-

91. 405 U.S. at 149.

92. 403 U.S. 431 (1971).

93. 405 U.S. at $146-47$.

94. Texas did not permit write-in votes in primary elections. TEX. ElECTION CODE ANN. art. 13.09(b) (1967). Nor did it or any other state permit candidates to avoid a filing fee by filing a pauper's affidavit. Following Carter v. Dies, 321 F. Supp. 1358 (N.D. Tex. 1970), however, the Texas Legislature approved a ballot eligibility provision permitting a nominating petition and a pauper's affidavit in lieu of a filing fee. TEX. Election Code ANN. art. 13.07a (Supp. 1971).

95. "[T]o force a candidate to seek election [by write-in vote], is to throw too many hurdles in his path solely because he is without funds to qualify." Jenness v. Little, 306 F. Supp. 925, 929 (N.D. Ga. 1969). Accord, Socialist Workers Party v. Welch, 334 F. Supp. 179, 182-83 (S.D. Tex. 1971); Wong v. Mihaly, 332 F. Supp. 165,168 (N.D. Cal. 1971). The lower courts' determination of the inadequacy of a write-in alternative is consistent with Williams v. Rhodes, 393 U.S. 23 (1968), in which the Supreme Court held that the unconstitutionality of an Ohio law requiring a nommating petition signed by voters totalling 15 percent of the number of ballots cast in the preceding state gubernatorial election as a precondition to getting a spot on the presidcntial ballot was not cured by a write-in alternative.

96. Sociahist Workers Party v. Welch, 334 F. Supp. 179, 185 (S.D. Tex. 1971); Duncantell v. City of Houston, 333 F. Supp. 973, 976 (S.D. Tex. 1971); Wong v. Mihaly, 332 F. Supp. 165, 169 (N.D. Cal. 1971); Georgia Socialist Workers Party v. Forston, 315 F. Supp. 1035, 1041 (N.D. Ga. 1970); Jenness v. Little, 306 F. Supp. 925, 929 (N.D. Ga. 1969).

97. 383 U.S. 663 (1966). 
paper facilities should be subject to the same constitutional scrutiny as candidate filing fees.

II.

\section{TeleVision AND Radio EXPENSES}

\section{A. The Scope of the Problem}

Clearly, elimination of filing fee requirements does little to ease the inequities caused by the high cost of running an effective campaign. Campaign costs are enormous, and they continue to grow every year. In 1968, for example, candidates for local, state, and federal offices across the country spent $\$ 300$ million campaigning, a 50 percent imcrease over the 1964 election, even though campaign expenditures rose by only 43 percent from 1952 to $1964 . .^{08}$ In presidential campaigns alone, the price per vote has risen from 19 cents in 1952 , to 32 cents in 1960 , to 41 cents in 1964 and finally to 60 cents in $1968 .{ }^{\circ 9}$ One of the major reasons for this rapid rise is the growing belief that television is an indispensable campaign tool ${ }^{100}$-and television is enormously expensive.

In 1970 , candidates in all elections spent $\$ 50.3$ million on radio and television, ${ }^{101}$ an amount 57 percent greater than that spent in 1966, the preceding nonpresidential election year. ${ }^{102}$ Although there

98. H. AleXANDER, Financing THE 1968 Election 1 (1971).

99. Id. at 4.

100. Candidates are relying more than ever on the electronic media to reach the electorate. As the Twentieth Century Fund Commission on Campaign Costs im the Electronic Era reported [in Voters' TIME, at 8 (1969)], “. . . the fact that many politicians believe that broadcasting is of major importance tends to make it so." And such beliefs appear justified; a candidates can reach more people by purchasing broadcast time than by the use of any other medium. Ninety-five percent of all American homes have television sets. The average American home has its television set turned on $5 \frac{1}{2}$ hours daily. Indeed adult Americans spend more time watching television than in any other activity with the sole exception of sleeping. Finally, radio and television are the major source of most news, including news about candidates for national and state offices.

Hearings on H.R. 13721, H.R. 13722, H.R. 13751, H.R. 13752, H.R. 13935, H.R. 14047, H.R. 14511 and S. 3637 Before the Subcomm. on Communications and Power of the House Comm. on Interstate and Foreign Commerce, 91st Cong., 2d Scss., at 7 (1970) (testimony of Dean Burch, Chairman of the Federal Communications Commission) [hereinafter cited as 1970 Hearings].

101. N.Y. Times, June 18, 1971, at 13, col. 3 (reporting statistics compiled by the FCC). FCC figures do not include production and promotion costs. which, in the opinion of Herbert E. Alexander of the Citizens' Research Foundation, add 20 to 33 percent to the FCC statistics. He further estimates that when the cost of campaigu staff time, travel, and fund raising related to broadcast nceds is considered, television and radio costs become the single largest item in most campaign budgets. 1970 Hearings, supra note 100, at 93 (testimony of Herbert E. Alexander).

102. N.Y. Times, June 18,1971 , at 13 , col. 3. The Democrats spent $\$ 26$ million; Republicans, $\$ 21.7$ million; minor party candidates, $\$ 2.7$ million. Senatorial can- 
is no clearcut pattern suggesting that candidates who spend the most money on radio and television have the best change of winning, ${ }^{103}$ statistics do suggest that almost any candidate who entertains serious hopes of winning a national or statewide office inust set aside a significant anount of money for radio and television advertising. In 1970, for instance, the 35 winners of gubernatorial seats spent an average of $\$ 145,883$ on the electronic media. ${ }^{104}$ The 33 senatorial winners spent an average of $\$ 123,803$. $^{105}$

Running for office can also be prohibitively expensive at the local level. In the 1971 race for mayor of San Francisco, the three major candidates reported expenditures totaling nearly $\$ 1$ million, ${ }^{106}$ or $\$ 4.27$ for every vote received, ${ }^{107}$ thus far exceeding the 60 cents per vote figure in the 1968 presidential election. Over one-third of the $\$ 1$ million went for radio and television. ${ }^{108}$ For a $\$ 9,200$ a year seat on the San Francisco Board of Supervisors, one candidate spent \$99,371.65 in 1971 , one-fifth of which was spent on radio and television. $^{100}$ Another candidate spent $\$ 86,000$, more than one-third of which was spent on television and radio. ${ }^{110}$ In fact, of the 33 persons who ran for the vacant seats on the San Francisco Board of Supervisors in 1971 , the six winners spent almost $\$ 420,000$, inore than twice that spent by all 27 losers combined. ${ }^{111}$ The six winners spent

didates spent $\$ 13.6$ million; House candidates. $\$ 15.2$ million; candidates for governor and lieutenant governor, $\$ 15.9$ million; and seekers of local offices, $\$ 15.6$ million. In the general election alone senatorial candidates spent $\$ 8.6$ million; House candidates, $\$ 3.9$ million; candidates for goveznor and lieutenant governor, $\$ 9.8$ million; and other candidates, $\$ 8.5$ million.

103. In the 33 senatorial campaigns in 1970 , the lighest spenders on radio and television won 18 contests and lost 15. N.Y. Times, May 12, 1971, at 20, col. 3. In the 35 gubernatorial races in 1970, 19 of the top television and radio spenders won, while 16 lost. Id. June 18, 1971, at 12, col. 4 .

104. Computed froin figures reported in the N.Y. Times, June 18, 1971, at 12, col. 3.

105. Computed from figures reported in the N.Y. Times, May 12, 1971, at 20, col. 3. See note 125 infra.

106. Joseph Alioto, \$547,376; Diane Feinstein, \$222,039; Harold Dobbs, \$179,109. Candidate spending reports on file with the Registrar of Voters, City and County of San Francisco.

107. San Francisco Chronicle, Dec. 13, 1971, at 10, col. 1.

108. Alioto, $\$ 197,910$; Feinstem, $\$ 131,993$; Dobbs, $\$ 50,403$. Candidate spending reports on file with the Registrar of Voters, City and County of San Francisco. These figures, unlike national figures gathered by the FCC, include the cost of producing advertising spots.

109. The candidate was Robert $\mathrm{H}$. Mendelsohn. Candidate spending reports on file with the Registrar of Voters, City and County of San Francisco.

110. The candidate was Ron Pelosi. Id.

111. The six winners spent a total of $\$ 416,121$. Twenty-five of the losing candidates spent a total of $\$ 173,800$. Two candidates did not report their expenditures. Totals counputed from candidate spending reports on file with Registrar of Voters, City and County of San Francisco. 
$\$ 78,000$ on radio and television; the 27 losers spent only $\$ 15,000 . .^{112}$

\section{B. Legislative Remedies: The Federal Election Campaign Act of 1971 and the Revenue Act of 1971}

Congress stepped in to check the steady rise of campaign expenditures when it approved the Federal Election Campaign Act of $1971,{ }^{113}$ which limits the amount of money that candidates for federal office may spend on advertising. Candidates may spend no more than 10 cents per voting age citizen or $\$ 50,000$, whichever is greater, on radio, television, newspaper, magazine, billboard, and telephone advertismg. ${ }^{114}$ No more than 60 percent of that amount may be spent on the electronic media. ${ }^{115}$

Although the Act is commendably motivated, it raises disturbing constitutional issues. ${ }^{116}$ A fundamental question, for example, is whether limits on campaign expenditures restrict a candidate's first amendment right of free political expression. ${ }^{117}$ The Act may also violate the first amendment rights of a candidate's supporters since it requires all spending for a candidate to be approved by the candidate limiself and imcluded in his spending quota. ${ }^{118}$ As a consequence, candidates have censorship power over the political expression of their supporters that they may exercise if they have reached their ceiling or even if they would find such support embarrassing or politically inopportune. ${ }^{119}$

112. Id.

113. Pub. L. No. 92-225, 86 Stat. 3 (Feb. 7, 1972).

114. Id. $\S \S 102,104(\mathrm{a})(1)(\mathrm{A})(\mathrm{i})$-(ii). The Act provides for an increase in the $\$ 50,000$ minimum ceiling commensurate with increases in the cost-of-living index. Id. $\$ 104$ (a) (4). Accordingly, the minimum ceiling for the 1972 election is $\$ 52,150$ to account for the 4.3 percent increase of the cost of living in 1971. BrosdCastino, Apr. 24, 1972, at 22.

115. Id. \& $104(\mathrm{a})(1)(\mathrm{B})$.

116. See generally Gartner, Campaign Financing: A Dubious Law, Wall Street Journal, Apr. 5, 1972, at 16, col. 4; Redish, Campaign Spending Laws and the First Amendment, 46 N.Y.U.L. Rev. 900 (1971); Note, Free Speech Implications of Campaign Expenditure Ceilings, 7 HaRv. Civ. Righrs-Civ. Lib. L. Rev. 214 (1972); Note, Campaign Spending Regulation: Failure of the First Step, 8 HARv. J. LEGIS. 640 (1971).

117. See, e.g., Mills v. Alabama, 384 U.S. 214, 218-20 (1966) (law prohibiting voter solicitation on election day unconstitutional as applied to newspaper editorial since a major purpose of the first amendment is to protect free discussion of political affairs).

118. Pub. L. No. 92-225, § 104(b), 86 Stat. 3 (Feb. 7, 1972).

119. In Altoona Trans-Audio Corp. v. Klemdienst, Civil No. $637-72$ (D.D.C. May 11, 1972), a three-judge court rejected a challenge by a group of broadcasters to the Federal Election Campaign Act based on four theories: (1) the spending ceilings abridge the public's first amendment right to receive access to ideas; (2) requiring candidates to certify all advertisements on their behalf violates their supporters' first aniendment rights; ( 3 ) limiting what broadcasters may chargc candidates to the 
The Act also contains strict contribution disclosure provisions that are equally constitutionally suspect. Candidates and political committees must report the name, address, occupation, and principal place of business of all persons who contribute inore than $\$ 100$ to a political campaign. ${ }^{120}$ Such a provision threatens "the recently developed first amendment right of anonymity."121 The danger is not that contributors will be exposed, but that potential contributors, fearful of exposure, will be deterred from exercising their first amendment right of political association. ${ }^{122}$

Besides its questionable constitutionality, the Act suffers from other serious flaws. By imposing a spending ceiling without providing any minimum subsidy, for example, the Act favors incumbents

"lowest unit charge" is confiscatory im violation of the fifth amendment; (4) the Act discriminates against broadcasters and in favor of newspapers and magazines. The court easily disposed of the third and fourth claims, but noted that the first amendment claims might have merit, particularly the one challenging the requirement that a candidate certify advertisements on his behalf. The court concluded, however, that the issue was not yet ripe for adjudication and could only be properly evaluated after the Act had been in operation for a time.

120. Id. $\S 304$. This section has at least one glaring loophole. A contributor may send a check to one of four committees (Republican senatorial, Democratic senatorial, Republican congressional, Democratic congressional) with the understanding that a matching check will be sent to candidate $X$. Thus, the candidate need only report that he received a contribution from his party's committee. Polk, Congressional Campaign Contributions: Harder to Conceal, New Republic, Apr. 22, 1972, at 18.

121. Redish, supra note 116, at 925. See Shelton v. Tucker, 364 U.S. 479 (1960) (statute requiring teachers to disclose all affiliations with and contributions to organizations violates first amendment); Talley v. California, 362 U.S. 60 (1960) (ordinance requiring all handbills to list names of printer and author unconstitutionally restricts freedom of expression); NAACP v. Alabama, 357 U.S. 449 (1958) (compulsory disclosure of NAACP membership hist would violate first amendment freedom of association). But see also United States v. Harriss, 347 U.S. 612 (1954) (paid lobbyists may be statutorily required to identify all persons who contribute $\$ 500$ or more to support their activities); Burroughs v. United States, 290 U.S. 534 (1934) (Federal Corrupt Practices Act, which requires disclosure of the identity of all contributors of $\$ 100$ or more to certain pohtical organizations, is constitutional).

122. Whether or not the spending ceiling and the disclosure requirements of the Federal Election Campaign Act violate the first amendment may depend on whether the Supreme Conrt applies a strict clear-and-present-danger type test [Brandenburg v. Ohio, 395 U.S. 444, 447 (1969); Schenck v. United States, 249 U.S. 47, 52 (1919);I or a balancing test [Komigsberg v. State Bar, 366 U.S. 36, 51 (1961); Barenblatt v. United States, 360 U.S. 109, 126 (1959)]. Under the first test, it would be difficult to show that the evils attacked by the Federal Election Campaign Act present the sort of clear and present threat to societal order that justifies limitations on first amendment freedoms. Under the Court's balancing test, on the other hand, the question would be whether the democratic benefits of more equal access to the political arena and greater knowledge of candidate financial support outweigh the attendant restrictions on first amendment expression and association. See Note, Free Speech Implications of Campaign Expenditure Ceilings, 7 HARv. Civ. RIGHTS-Crv. LIB. L. REv. 214, 223 (1972) and S. Rep. No. 92-96, U.S. Code Cong. \& Ad. News, 92d Cong., 2d Sess., 56-57 (1971) for view that balancing test applies. 
since the unknown candidate must often spend far more than his opponent in order to overcome the officeholder's ready recognition with the public. ${ }^{123}$ And, of course, poor candidates remain disadvantaged. The Act also falls far short of relieving candidates of the need to seek substantial financial backing since the spending ceilings are not really very stringent. In 1968, for example, although Richard Nixon's expenditures on the electronic media exceeded the ceiling proposed for 1972 by $\$ 4.3$ million, Hubert Humphrey fell $\$ 2.3$ million short of the ceiling. ${ }^{124}$ Moreover, only 21 of the 68 major candidates in the 1970 Senate elections spent an amount in excess of the statewide ceilings proposed for the 1972 elections. ${ }^{125}$ Another distrubing flaw is that the Act leaves state and local elections largely unregulated. ${ }^{26}$ Finally, with or without spending ceilings, fundamental inequities between candidates on the basis of wealth and their ability to attract substantial financial support will remain as long as political canpaigns are financed solely by private sources rather than, at least in some portion, by the government.

In 1971, Congress passed and the President signed the Revenue Act of $1971,{ }^{127}$ which, in part, provides a means for presidental and vice-presidential candidates to receive public financing for their campaigns. ${ }^{128}$ Beginning in 1973, taxpayers may check off $\$ 1$ on their tax returns for contributions to the presidential campaign of any political party that received at least 5 percent of the vote in the previous presidential election. ${ }^{129}$ Minor parties-those that received between

123. Moreover, the Act fails to account for subsidies of incumbents from the franking privilege, free telephone use, and free travel to home states. The way the Act favors incumbents may also raise a constitutional issue: a candidate's first amendment right to present himself to the voters and voice his political views and his supporters' first amendment right of pohtical association may be seriously hindered if the government imposes restrictions that appreciably benefit one candidate more than another. Cf. Williams v. Rhodes, 393 U.S. 23 (1968) (complicated ballot barriers violate freedom of political association). But see Lippitt v. Cipollone, 404 U.S. 1032 (1972) (statute denying a candidate the right to run in a party primary if he voted as a member of a different party within the preceding 4 years does not unconstitutionally impair his right of political expressiou).

124. The 1972 ceiling of 6 cents per voting age person in the nation establishes an $\$ 8.55$ million total spending limit for radio and television advertising. BronDCAsting, Apr. 24, 1972, at 22. Figures compiled by the FCC indicate that in 1968 Republicans spent $\$ 12.2$ million on Richard Nixon's radio and television advertising while Democrats spent $\$ 6.1$ for Hubert Humphrey. N.Y. Times, May 12, 1971, at 20 , col. 3.

125. See the chart listing 1970 campaign expenditures in the appendix.

126. See note 9 supra.

127. Revenue Act of Dec. 10, 1971, Pub. L. No. 92-178, 85 Stat. 497.

128. Id. $\$ 801$.

129. $\$ 2$ may be deducted on joint returns. Alternatively, a taxpayer may choose to contribute to a nonpartisan fund for distribution among eligible parties. Id. $\S 6096(\mathrm{~g})$. 
5 and 20 percent of the vote in the previous presidential election-are entitled to a percentage of the subsidy received by the major parties depending upon their percentage support in the previous election. ${ }^{130}$ Candidates who choose to take advantage of public financing will be able to spend in their campaigns no more than 15 cents times the number of voting age persons in the country. They may use private donations only if the fund allocated to them does not reach the spending ceiling. ${ }^{131}$ Candidates in presidential primaries ${ }^{132}$ and candidates for Congress, statewide offices, and local offices, however, are not benefited by the Act. Consequently, the need for involving the government in the financing of all elections, save presidential elections, remains.

While recognizing the potential superiority of a comprehensive legislative approach to the problem, this Comment suggests, in the absence of effective legislation, a judicial approach based on the first amendinent and the equal protection clause of the fourteenth amendment. Although it is beyond the function of the judiciary to legislate a more equitable system, it is duty bound to declare unconstitutional those parts of the present system that violate those basic rights; this, in turn, may compel the legislative branch to move quickly to fashion a more equitable and effective substitute. Accordingly, the next section discusses the constitutionality of the way campaign advertising on television and radio is allocated by focusing on the following question: Do the first amendment and the equal protection clause of the fourteenth amendment require a radio or television licensee to give free time to an indigent candidate if his opponent has paid for and been granted advertising time? ${ }^{133}$

130. Id. $\S 9004$ (a)(2). A new party, whose support in the previous election failed to reach 5 percent, can get money after the election if it receives at least 5 percent of the vote. Id. $\$ 9004(\mathrm{a})(3)$.

131. Id. §§ 9003(b)(2), 9004(a)(1).

132. Candidates for president spent more than $\$ 45$ million in primaries alone in 1968. Richard Nixon spent over $\$ 10$ million; Nelson Rockefeller spent $\$ 8$ million; George Romney, $\$ 1.5$ million; Ronald Reagan, $\$ 750,000$; Harold Stassen, $\$ 90,000$; Eugene McCarthy, $\$ 11$ million; Robert Kennedy, $\$ 9$ million; Johnson and Humphrey together, \$5 million; George McGovern, $\$ 74,000$; and Lester Maddox, $\$ 50,000$. H.E. Alexander, Financing the 1968 Campaign 10, 30 (1971). The 1972 Democratic presidential contenders agreed to limit their primary spending on broadcast, print, and billboards to 5 cents for each registered voter in each state. Each candidate was also permitted to draw on an additional pool of 5 percent of the total ceiling-or about $\$ 142,000$-one-third at a time to increase spending in three primaries. BROADCASTING, Dec. 6, 1971, at 10.

133. This Comment does not discuss the problems raised when a station grants one candidate a gratuitous appearance without giving the same opportunity to his opponent. The Federal Communications Commission commonly faces this issue and must deternine under section 315 of the Federal Communications Act [47 U.S.C. $\S 315(1970)$ ] when free time has been given and who is a legally qualified candidate 


\section{The Impact of the Equal Protection Clause and the First Amendment on Paid Political Broadcast Advertising}

Section 315(a) of the Federal Communications Act, ${ }^{134}$ popularly known as the equal time provision, establishes guidelines to be followed by broadcasting licensees in providing campaign time for political candidates. The pertinent language reads:

If any licensee shall permit any person who is a legally qualified candidate for any public office to use a broadcasting station, he shall afford equal opportunities to all other such candidates for that office in the use of such broadcasting station . . . . ${ }^{\mathbf{1 3 5}}$

The Federal Communications Commission las interpreted the phrase "equal opportunities" to mean simply that there must be no discrimination in time periods, rates, facilities, or services between candidates. ${ }^{130}$ The FCC has declared that it does not mean that a station must donate time to a candidate who cannot afford time comparable to that paid for by his opponent. ${ }^{137}$ As a consequence, although section 315(a) is neutral on its face-by its plain language it does not discriminate against any class of persons-it nonetheless has a discriminatory effect. ${ }^{138}$ Licensees are permitted to provide broadcasting time to those

eligible to lay claim to equal time. See Use of Broadcast Facilities by Candidates for Public Office, 3 F.C.C.2d 436, 468-88 (1966), for a detailed review of the Commission's treatment of this issue.

134. 47 U.S.C. $\$ 315$ (a) (1970). There is a great deal of dissatisfaction with section 315. It is criticized in its present form for discouraging licensees from providing free time for major candidates since they would then be obligated to provide equal free time to all minority candidates. Scott, Candidate Broadcast Time: A Proposal for Section 315 of the Communications Act, 56 Geo. L.J. 1037, 1038 (1968). In 1960, section 315 was suspended for the televised Kennedy-Nixon debates. Act of Aug. 24, 1960, Pub. L. No. 86-677, 74 Stat. 544. This too was criticized for effectively excluding minority parties from any serious voter consideration. Blaine, Equality, Fairness and 315: The Frustration of Democratic Politics, 24 MD. L. Rev. 166,168 (1964). There have been several proposals to modify section 315 to satisfy the twin goals of reasonably equitable time for all candidates and an informed and palatable presentation of the major campaign issues and personalities to the voters. See Derby, Section 315: Analysis and Proposal, 3 HaRv. J. LEgIs. 257, 315-21 (1966); Friedenthal \& Medahe, The Impact of Federal Regulation on Political Broadcasting: Section 315 of the Communications Act, 72 HARv. L. Rev. 445 (1959); Geller, Political Broadcasts-A Few Short Steps, 20 CATH. U.L. REv. 449, 454-62 (1972); Scott, supra at 1046-49; Singer, F.C.C. and Equal Time: Never Never Land, Revisited, 27 MD. L. REv. 221, 242-51 (1967).

135. 47 U.S.C. \& 315(a) (1970).

136. Use of Broadcast Facilities by Candidates for Public Office, 3 F.C.C.2d 463, 466 (1966).

137. Letter to M.R. Oliver, 11 P \& F Radro Reg. 239 (1952).

138. In each case in which the Supreme Court has required a statute or practice that discriminated against the poor to meet strict equal protection scrutiny, the challenged statute or practice lias been discriminatory iu effect. Bullock v. Carter, 405 U.S. 134 (1972); Tate v. Short, 401 U.S. 395 (1971); Williams v. Illinois, 
who can afford to pay for it, but they are not required to provide equal treatment to those who cannot afford to pay. As a result, candidates with money and candidates without money are plainly the subject of different treatment.

In short, like a filing fee regulation, section 315(a) is applied in a fashion that places a heavier burden on indigent political candidates than it does on nonindigent candidates. In light of the importance of broadcasting advertising in many elections, ${ }^{139}$ one can argue that the FCC's interpretation of "equal opportunities" falls within the penumbra of the Supreme Court's language in Bullock.

Many potential office seekers lacking both personal wealth and affluent backers are in every practical sense precluded from seeking the nomination of their chosen party, no natter how qualified they might be and no matter how broad or enthusiastic their popular support. ${ }^{140}$

Similarly, the practical effect of section 315 (a) is to exclude many imdigent candidates and candidates without wealthy supporters from serious voter consideration, on the assumption, at least with regard to most elections, that a certain anount of broadcast exposure is virtually essential before any candidate can mount a viable campaign. Furthermore, the Court in Bullock recognized that a candidate who could not pay a filing fee might be the choice of the "less affluent segment of the community,"141 and a similar proposition holds for a person unable to purchase broadcast time. Both the indigent candidate and the less affluent voter are inhibited in the exercise of basic privileges for strictly economic reasons. ${ }^{142}$

There are, of course, imiportant differences between the Texas filing fee scheme struck down im Bullock and section 315(a). First, it appears, at least at first, that while the filing fee scheme in Bullock totally denied indigent plaintiffs the opportunity to run for office, section 315(a) is applied in a way that simply denies indigent candidates the right to run for office effectively. Second, whereas in Bullock a

399 U.S. 235 (1970); Harper v. Virginia Bd. of Elections, 383 U.S. 663 (1966); Douglas v. California, 372 U.S. 353 (1963); Griffin v. Illinois, 351 U.S. 12 (1956). 139. One commentator has noted: "Mass communication is no longer a luxury of politics; it is often the very essence." Singer, supra note 134, at 246 . On the other hand, some commentators feel the importance of the electronic media in effecting political consciousness is greatly exaggerated. See e.g., Jaffe, The Editorial Responsibility of the Broadcaster: Reflections on Fairness and Access, 85 HARv. L. REv. 768, 768-71 (1972). See also R. MacNeIr, The People Machine 222-23 (1968), noting that, in the opinion of pohtical professionals, television is most effective in swaying indifferent, lower middle class voters.

140. 405 U.S. 134, 143 (1972).

141. Id. at 144.

142. The language of Bullock is particularly apt here. See Id. 
state statute imposed the fee on all candidates, section 315(a) merely requires a privately owned broadcast station to afford equal opportunities to candidate $X$ if it has provided broadcast time to candidate $Y$. Thus, the question is whether there is sufficient governmental involvement to compel constitutional review. ${ }^{143}$

\section{The Right to Run for Office Effectively}

Close scrutiny of Bullock reveals that the first difference may not be significant. The challenged filing fee in Bullock did not deny plaintiffs the right to run for office; rather, it prevented thein from running for their party's nomination. Plaintiffs could still gain a place on the ballot in the general election by submitting a nominating petition. ${ }^{144}$ The Court declared that it was unreasonable to require candidates to abandon their party affiliation in order to avoid a filing fee and noted that in certain parts of Texas where the Denocratic Party predominates, the primary election may be more crucial than the general election. ${ }^{145}$ Thus, the Court in Bullock invalidated Texas's filing fee scheme, not because it denied the right to run for office, but because it abridged the right to run for office in an effective manner. Similarly, section 315(a) abridges an indigent candidate's right to run an effective campaign in locales where access to the broadcast media is as crucial to a serious campaign as access to the primary ballot is in some parts of Texas.

The notion that a candidate should not be prevented from campaigning effectively is supported by the emerging first amendment doctrine that since freedom of speech entails effective speech in an appropriate forum, ${ }^{146}$ there is therefore a first amendment right of access to the printed and broadcast media. ${ }^{147}$ This theory is grounded on the notion that the pervasive effect of the electronic media on the flow and availability of information today requires that broadcast hicensees take an affirmative role in assuring that both sides of controversial matters receive an airing. Such an approach has necessitated a somewhat different view of the first amendment's relation to the nuass media. Traditionally, debate has centered on whether the first amendment protects the nuass nedia from censorship, hibel suits, and other abridgements of

143. See note 170 infra and text accompanying notes 170-211 infra.

144. Id. at 146.

145. Id. See also Carter v. Dies, 321 F. Supp. 1358, 1363 (N.D. Tex. 1970) (Thornberry, J., concurring).

146. See cases cited at note 169 infra.

147. The leading exponent of this theory is Jerome A. Barron, whose views aro set forth in Barron, Access-The Only Choice for the Media?, 48 TEx. L. Rev. 766 (1970); Barron, An Emerging First Amendment Right of Access to the Media?, 37 Geo. Wash. L. REv. 487 (1969), and Barron, Access to the Press-A New First Amendment Right, 80 HARv. L. REv. 1641 (1967). 
freedom of the press. ${ }^{148}$ Two recent cases, ${ }^{149}$ however, have raised variations on a different first amendment issue: Does the first amendment afford private individuals or organizations a right of access to the electronic niedia?

In Red Lion Broadcasting Co. v. FCC, ${ }^{150}$ the Supreme Court reviewed the FCC's fairness doctrine. ${ }^{151}$ The fairness doctrine has evolved from a string of FCC decisions and imposes a two-fold duty on broadcasters. ${ }^{152}$ They must give adequate coverage to public issues, ${ }^{153}$ and such coverage inust be fair, accurately reflecting opposing views. ${ }^{154}$ If no sponsorship is available, balanced coverage must be provided at the broadcaster's expense ${ }^{155}$ and must be obtained from no other source. ${ }^{158}$ In 1959 , Congress codified the fairness doctrine in an amendment to section 315 of the Communications Act. ${ }^{157}$

The Court in Red Lion upheld the constitutionality of the fairness doctrine, and the FCC's personal attack regulation based thereon, ${ }^{158}$ against claims that it abridged the broadcaster's freedorn of speech. The Court declared that the fairness doctrine and the FCC regulations enhanced rather than abridged first amendment protections because it was the right of the public to liave access to ideas that was paramount, not the right of broadcasters to speak. ${ }^{159}$

In Red Lion the Court afforded judicial recognition to two important first amendment considerations. First, although it did not explicitly hold that a right to reply to personal attacks was constitutionally mandated, it did note that a right of reply "enhanced" first amendment rights and thus, implicitly acknowledged that only a right of reply

148. New York Times Co. v. United States, 403 U.S. 713 (1971); Rosenbloom v. Metromedia, Inc., 403 U.S. 29 (1971); Red Lion Broadcasting Co. v. FCC, 395 U.S. 367, 386-90 (1969); New York Times v. Sullivan, 376 U.S. 254 (1964); National Broadcasting Co. v. United States, 319 U.S. 190 (1943).

149. Red Lion Broadcasting Co. v. FCC, 395 U.S. 367 (1969); Business Executives' Move for Vietnam Peace v. FCC, 450 F.2d 642 (D.C. Cir. 1971), cert. granted, 405 U.S. 953 (1972).

150. 395 U.S. 367 (1969).

151. The fairness doctrine is based on the statutory requirement that broadcast licenses be granted in "public interest." 47 U.S.C. $\$ \$ 307$ (a), 309(a) (1970).

309 (a) (1970).

152. The evolution of the fairness doctrine is summarized in Red Lion Broadcasting Co. v. FCC, 395 U.S. 367, 377-81 (1969).

153. United Broadcasting Co., 10 F.C.C. 515 (1945).

154. New Broadcasting Co., 6 P \& F RADIo REg. 258 (1950).

155. Cullman Broadcasting Co., 40 F.C.C. 576 (1963).

156. John J. Deinpsey, 6 P \& F Radio ReG. 615 (1950).

157. "[Section 315 imposes upon broadcasters the obligation] to operate in the public interest and to afford reasonable opportunity for the discussion of conflicting views on issues of public importance." Act of Sept. 14, 1959, § 1, 73 Stat. 557, amending 47 U.S.C. $\$ 315$ (a).

158. 47 C.F.R. $\$ \$ 73.123,73.300,73.598,73.679$ (1972) (identical sections).

159. 395 U.S. at 375,390 . 
over the electronic niedia, as opposed to on a streetcorner or by leaflet, effectively fulfilled the right of free speech of one who has been personally attacked. ${ }^{160}$ The Court also acknowledged that a right to reply would be severely diminished if it were limited only to those persons able to purchase airtime or obtain paid sponsorship. Therefore, the Court approved FCC guidelines requiring bensees to supply reply time at their own expense.

There may be a danger in reading Red Lion too expansively. It did not expressly hold that the fairness doctrine was inandated by the first amendment, though the Court's declaration that the public's right to receive suitable access to a broad range of ideas "niay not . . . be abridged by Congress or by the FCC"161 nuakes such a conclusion virtually inescapable. ${ }^{162}$ Nor did it concern any section 315 problems regarding campaign broadcasts. Red Lion simply held that the fairness doctrine did not violate broadcasters' first amendment rights. Its language indicating that the fairness doctrine "enhances" first annendment rights and that, in many situations, speech of individuals has constitutional preference over speech of broadcasters must be noted, however, as an important breakthrough in first amendment thinking.

Even more striking recognition of the notion that free speech requires effective speech, which in turn necessitates access to the electronic media, is found in Business Executives' Move for Vietnam Peace (BEM) v. FCC. ${ }^{163} \quad B E M$ concerned an attempt by a businessmen's organization to purchase 1-minute advertising spots over a Washington, D.C. radio station to air its disapproval of United States involvement in the Vietnam War. The station refused this request citing its long established policy of not selling spot announcement timc for the discussion of views on controversial issues, ${ }^{164}$ and the FCC supported the station's stand. ${ }^{185}$ The Court of Appeals for the District of Columbia Circuit reversed, lowever, lolding that a station violates the first amendment when it bans paid public issue announceinents while accepting other types of paid announcements. ${ }^{186}$

The court grounded its decision on the theory that the first amendment requires an appropriate forum for the expression of con-

160. Cf. 395 U.S. at 386 n.15.

161. 395 U.S. at 390.

162. See Jaffe, supra note 139, at 774.

163. 450 F.2d 642 (D.C. Cir. 1971), cert. granted, 405 U.S. 953 (1972).

164. Id. at 647 .

165. Business Executives' Move for Vietnam Peace, 25 F.C.C.2d 242 (1970).

166. $450 \mathrm{~F} .2 \mathrm{~d}$ at 646 . In $B E M$, the court also considered a companion ruling by the FCC [Democratic National Committee, 25 F.C.C.2d 216 (1970)] that held that a station could refuse to sell time to the Democratic National Committee (DNC) for the discussion of timely political issues, though it could not refuse to sell the DNC time for advertisements to solicit funds. The court reversed the FCC ruling on the discussion of controversial political issues. 
stitutionally protected thought and that, at least for these petitioners, the electronic media afforded the nuost effective forum for that expression. The court noted that BEM's primary means of operation was public persuasion and communication, and thus, its influence depended upon its ability to be heard by the public. Furthermore, the Court felt that radio and television were clearly the most effective media for BEM's purposes. ${ }^{107}$ Stressing the growing importance of radio and television to the communication of ideas in this country, the court argued that first amendnent thinking must expand accordingly. ${ }^{168}$

$B E M$ is the first case to hold that in certain situations, electronically broadcasted speech nuay be the only effective way to exercise one's first amendment rights. ${ }^{169}$ As such, it dovetails nicely with the Supreme Court's assertion in Bullock that the equal protection clause prohibits discriminations on the basis of wealth which prevent political candidates from running for office in an effective fashion-in the case of Bullock, on the primary ballot rather than in the general election. Therefore, at least one plausible conclusion that can be drawn from a juxtaposition of Bullock and $B E M$ is that denying political candidates

167. 450 F.2d at 646 .

168. See 450 F.2d at 653 .

169. The United States Suprenie Court granted certiorari in BEM, 405 U.S. 953 (1972), and stayed the lower court's decision for the interim (Justice Douglas dissenting), thus suggesting that $B E M$ may not fare well on appeal. Nonetheless, the notion that free speech may not be absolutely restricted in appropriate forums where other activities are permitted is not new. Prior to $B E M$, however, that notion had never been applied to the electronic inedia. See Johnson \& Westen, A Twentieth-Century Soapbox: The Right to Purchase Radio and Television Time, 57 VA. L. Rev. 574, 580-82, 610-20 (1971). Public settings such as streets and parks [Hague v. CIO, 307 U.S. 496 (1939); Wollain v. Palm Springs, 59 Cal. 2d 276, 379 P.2d 481, 29 Cal. Rptr. 1 (1963)], a public library [Brown v. Louisiana, 383 U.S. 131 (1966)], the grounds of a state capitol building [Edwards v. South Carolina, 372 U.S. 229 (1963)], public schools [Tinker v. Des Moines Indepeudent Community School Dist., 393 U.S. 503 (1969)], the streets of a military base open to the public [Flower v. United States, 92 S. Ct. 1842 (1972) (per curiam)], a public bus terminal [Wolin v. Port of New York Authority, 392 F.2d 83 (2d Cir. 1968), cert. denied, 393 U.S. 940 (1963)], and a public railroad depot [In re Hoffman, 67 Cal. 2d 845, 434 P.2d 353, 64 Cal. Rptr. 97 (1967)] have all been considered appropriate places where one can picket, distribute leaflets, or speak with first amendment protection. The Supreme Court has afforded similar treatment to the privately owned streets and sidewalks of a "conipany town" [Marsh v. Alabama, 326 U.S. 501 (1946)] and to the passageways of a privately owned shopping center when the protest is related to the shopping center's operations [Amalgamated Food Enuployees Union Local 590 v. Logan Valley Plaza, Inc., 391 U.S. 308 (1968)] though not to the passageways of such a shopping center if the first amendment activity is unrelated to the center's operations [Lloyd Corp. v. Tanner, 92 S. Ct. 2219 (1972)] nor to jailhouse grounds [Adderley v. Florida, 385 U.S. 39 (1966)] or to the near vicinity of a courthouse [Cox v. Louisiana, 379 U.S. 536 (1965)]. See also Wirta v. Alameda-Contra Costa Transit Dist., 68 Cal. 2d 51, 434 P.2d 982, 64 Cal. Rptr. 430 (1967) (public transit district operating buses could not refuse, as a matter of policy, to sell space for peace advertisements). 
access to the electronic nedia, and thus effective communication of their ideas, on the basis of wealth, violates both the equal protection clause and the first amendment.

\section{State Action}

A second difference between Bullock and section 315(a) is that while the challenged Texas statute imposed a filing fee as a precondition to getting on the ballot, section 315(a) imposes no discriminatory fee-it simply prescribes that all candidates be afforded "equal opportunities." It is the FCC's interpretation of section 315(a), and the broadcasters' implementation of that interpretation, that results in poor candidates being deprived of broadcast time. A major question is whether these types of activities constitute the requisite governmental involvement to trigger constitutional scrutiny. ${ }^{170}$ While it is clear that the prohibitions of the 14th amendment with respect to state activities, and the fifth amendment with respect to activities of the federal government, do not extend to purely private actions, ${ }^{171}$ the Supreme Court has held that state action, as the term is used to refer to federal, state, and municipal activities, may be found if a private entity is carrying out a state function ${ }^{172}$ or is involved in activities in which the state is closely entwined. ${ }^{173}$

170. The fourteenth amendment reads: “. . . nor shall any State . . . deny to any person within its jurisdiction the equal protection of the laws." U.S. CoNST. amend. XIV, § 1. The fifth amendment provides: "No person shall ... be deprived of life, liberty, or property, without due process of law. . ." U.S. Const. amend. V. In Bolling v. Sharp, 347 U.S. 497 (1954), the Supreme Court held that mamtenance of racially segregated educational facilities immune from the restrictions of the equal protection clause of the fourteenth amendment, which only apply to activities of the states, violated due process as guaranteed by the fifth amendment. The Court noted that "the concepts of equal protection and due process both [stem] from our American ideal of fairness" and though they may not always be interchangeable, "diserimination may be so unjustifiable as to be violative of due process." Id. at 699. Despite the Court's cautious language, it is nearly inconceivable that discrimination prohibited when under color of state law would be permissible if under color of federal law. See Schneider v. Rusk, 377 U.S. 163 (1964) (federal statute that discrimmates between native born and naturalized citizens violates fifth amendment due process). See also LockHaRT, Kamisar, \& CHOPER, ConstituTIONAL LAW 1207 (1970) for the view that discrimmation against aliens may be the exceptional area in which the federal government has more latitude than state governments. In this Comment, the term "state action" is used im the general sense to refer to the equal protection and due process prohibitions under both the fourteenth and fifth ameudments.

171. Civil Rights Cases, 109 U.S. 3 (1883).

172. Amalgamated Food Employees Umion v. Logan Valley Plaza, 391 U.S. 308 (1968); Evans v. Newton, 382 U.S. 296 (1966); Terry v. Adauns, 345 U.S. 461 (1953); Marsh v. Alabama, 326 U.S. 501 (1946); Smith v. Allwright, 321 U.S. 649 (1944).

173. Burton v. Wilmington Parking Authority, 365 U.S. 715 (1961). 
In $B E M$, the Court had to determine whether the licensee's flat ban on controversial advertising was within the ambit of state action as required by the first amendment. ${ }^{174}$ The Court found state action generally because of the interdependent relationship between the broadcaster and the federal government, and more specifically, because the FCC had approved the licensee's stand, thereby placing the imprimatur of a government agency on the challenged action. ${ }^{175}$

The first of these rationales is based on the fact that radio and television stations are licensed by the federal government: ${ }^{\mathbf{1 7 6}}$ they enjoy exclusive state-granted use of particular channels or frequencies; they do not own the airwaves, but rather liold them in trust for the American people. ${ }^{177}$ Furthermore, broadcasters are required by statute to exercise their licenses in the public interest. ${ }^{178}$ The $B E M$ court felt that the broadcasting industry's intimate ties to government and to public service made it unlike any other regulated private business and brought it within the sweep of the Suprene Court's definition of state action in Burton v. Wilmington Parking Authority. ${ }^{179}$

The second rationale supporting the finding of state action in $B E M$ was that the FCC had approved the station's flat ban on editorial advertising; therefore, it was essentially action by the government itself through one of its regulatory agencies that was under review. ${ }^{180}$ Such an analysis could be applied to any complaint agaimst broadcasters since complainants are required to seek relief from the FCC before re-

174. The first amendment provides that "Congress shall make no law ... abridging the freedom of speech. ..." Although by its plain language, the first amendment is applicable only to the national government, the Supreme Court has extended its coverage to actions by the states. Gitlow v. New York, 268 U.S. 652, 666 (1925). Even though $B E M$ discusses state action in the first amendment context, its analysis is equally applicable to equal protection problems. See Business Executives" Move for Vietnam Peace v. FCC, 450 F.2d at 651 n.15.

175. Business Executives' Move for Vietnam Peace v. FCC, 450 F.2d at 652.

176. 47 U.S.C. $\$ 301$ (1970).

177. See Red Lion Broadcasting Co. v. FCC, 395 U.S. 367, 394 (1969); Business Executives' Move for Vietnam Peace v. FCC, 450 F.2d 642, 652 (D.C. Cir. 1971); Office of Communications, United Church of Christ v. FCC, 359 F.2d 994, 1003 (D.C. Cir. 1966) (Burger, J.).

178. 47 U.S.C. $\$ 315(4)$. See S. Rep. No. 562, 86th Cong., 1st Sess. 8-9 (1959), quoted with approval in Red Liou Broadcasting Co. v. FCC, 395 U.S. 367, 383 (1969).

179. 450 F.2d at 652. In Burton v. Wilmington Parking Authority, 365 U.S. 715, 721-26 (1961), the Court held that racial discrimination by a restaurant which leased its space from the state and which enjoyed certain advantages by virtue of that leasehold was state action under the fourteenth ameudment because such governmental entwinement made the state a joint participant in the challenged activity.

180. 450 F.2d at 652-53, citing Public Utilities Comm'n v. Pollak, 343 U.S. 451, 462 (1952) (private bus company franchised by the federal government and regulated by a congressionally created public utilities commission was a government entity for constitutional purposes; state action particularly since the Commission lad investigated and dismissed the charges against the bus company). 
sorting to the courts. As a consequence, a court only reviews alleged discrimination by a broadcaster after the FCC has given its stamp of approval to the challenged action. An indigent candidate could base an argument for state action on this rationale if the FCC affirmed a station's denial of campaign broadcast time, as it has done in the past, by ruling that the "equal opportunities" provision of section 315(a) does not require a licensee to grant free time to a candidate simply because it has sold time to his opponent. ${ }^{181}$

Two recent Supreme Court decisions ${ }^{182}$ suggest that the Court is now anxious to check any further expansion of state action doctrine. The cases reevaluate three separate theories upon which the Court has based a finding of state action in the past: (1) private entity carrying out a state function; ${ }^{183}$ (2) entanglement between a private entity and the state; $;^{184}$ and (3) state sanction of private discrimination. ${ }^{185} B E M$, which the Supreme Court has agreed to hear on appeal, ${ }^{180}$ relied upon the latter two theories, and writers elsewhere have apphed the first theory to radio and television. ${ }^{187}$ The Court's recent treatment of state action, therefore, deserves attention.

\section{a. Private Entity Carrying out a Public Function}

Marsh v. Alabama ${ }^{188}$ and Amalgamated Food Employees Union v. Logan Valley Plaza ${ }^{189}$ have been standard bearers for the proposition that privately owned areas that are utilized so as to become "the functional equivalent of [a] business district"190 must bear all the constitutional obhgations of a government entity. Marsh concerned the right to distribute leaflets in a private company town, and Logan Val-

181. See text accompanying notes 136-37 supra. The FCC has also held that section 315 (a) does not apply when a candidate's supporters are sold air time, though the fairness doctrine does apply. Nicholas Zapple, 19 P \& F Radio REg. 2d 421 (1970). The Coinmission held, however, that the free time requirement normally applicable to fairness doctrine situations under the Cullmau doctrine [see note 155 supra and accompanying text] would not apply in this instance. In a concurring opinion, Comsioner Nicholas Johnson noted that free time for indigents might be constitutionally required. Id. at 426 .

182. Lloyd Corp. v. Tanner, 92 S. Ct. 2219 (1972); Moose Lodge No. 107 v. Irvis, 92 S. Ct. 1965 (1972).

183. See Amalgamated Food Employees Umion v. Logan Valley Plaza, 391 U.S. 308 (1968); Evans v. Newton, 382 U.S. 296 (1966); Marsh v. Alabama, 326 U.S. 501 (1946).

184. See Burton v. Wilmington Parking Authority, 365 U.S. 715 (1961).

185. See Reitman v. Mulkey, 387 U.S. 369 (1967); Shelley v. Kraemer, 334 U.S. 1 (1948). Cf. Public Utilities Comm'n v. Pollack, 343 U.S. 451, 462 (1952).

186. 405 U.S. 953 (1972).

187. See, e.g., Johnson \& Westen, supra note 169 , at 589-92.

188. 326 U.S. 501 (1946).

189. 391 U.S. 308 (1968).

190. Id. at 318. 
ley involved the right to picket in a privately owned shopping center to protest the hiring practices of one of the center's stores.

The Supreme Court significantly narrowed both decisions in the recent case of Lloyd Corp. v. Tanner, ${ }^{191}$ where it held that antiwar protesters had no first amendment right to distribute handbills im a privately owned shopping center not much different from Logan Valley Plaza. $^{192}$ The Court skillfully distinguished Marsh and Logan Valley. The company town in Marsh, the Lloyd Court contended, was an historical anomaly of little relevance to the modern problems raised by large shopping center coinplexes. ${ }^{193}$ The Court further asserted that Logan Valley's suggestion that, for first amendment purposes, the passageways of a shopping center are the equivalent of municipal streets and sidewalks was unnecessary to the decision and therefore mere dictum..$^{184}$ Logan Valley was said to apply only to its peculiar facts and not to first amendment activities unrelated to the shopping center's operations. ${ }^{195}$ In short, union picketers enjoy first amendment protection in privately owned shopping centers, but antiwar protesters, religious colporteurs, and political campaigners do not. ${ }^{196}$

Lloyd illustrates a marked lack of sympathy for the governmental function theory of state action, which the Court now apparently feels should be limited to only the most traditional free speech forums (such, as in Marsh, downtown streets and sidewalks). It may be argued, of course, that broadcasters are a quasi-governmental entity because of the important public functions radio and television communication performs ${ }^{197}$ coupled with the elaborate scheme by which broadcasters are regulated. In light of Lloyd, however, it is clear that a finding of state action under that theory would be a significant departure froin current Suprenie Court thinking.

191. 92 S. Ct. 2219 (1972).

192. In fact, Justice Marshall, dissenting, argued that Lloyd Center was of even more a public nature than Logan Valley Plaza and was, imdeed, more similar to the company town in Marsh than to Logan Valley. Id. at 2230-31.

193. Id.

194. Id. at 2226.

195. Id.

196. Even union picketers will have to select their forums carefully. In a case decided the same day as Lloyd, the Court lield that union organizers did not lave first amendment protection to solicit members in the parking lot of a large nonunion store. The Court distinguished Logan Valley on the ground that the store was not part of a shopping center complex. Central Hardware Co. v. NLRB, $92 \mathrm{~S}$. Ct. 2238 (1972).

197. For example, the President frequently uses radio and television to present his views to the public; it is an important electioneering device during political campaigns; and it is the principle meclianism that would be used to notify the public of emergency procedures during a national alert. 


\section{b. State Entanglement in Private Activities}

In Moose Lodge No. 107 v. Irvis, ${ }^{108}$ a black was refused service at the bar and dining room of a private club. While conceding that discrimination by purely private organizations is immune froin constitutional review, the plaintiff contended that the club's dependence upon the state for a liquor license entwined the state in the club's racial discrimination to an extent forbidden by the equal protection clause. The plaintiff sought to enjom the state froin licensing Moose Lodge as long as it continued discriminating against blacks.

The Court found the government imvolvement with Moose Lodge to be inconsequential, lowever, and asserted that extending state action coverage to any private entity that receives a governmental benefit or is subject to governmental regulation would eviscerate the traditional constitutional distinction between private and state conduct. ${ }^{199}$ The Court acknowledged that Moose Lodge was subject to detailed state regulation, but declared that this would only be significant if the regulations served to "foster or encourage" racial discrimination or made the state "a partner or . . . joint venturer" in the club's business. And even though the state licensing scheine limited the number of liquor licenses permitted in each locality, according to the Court, there were far too many hotel, restaurant, and retail licensees to suggest that club licensees enjoyed a liquor dispensing monopoly. ${ }^{200}$

Although Moose Lodge reversed a trend in the lower courts toward expanding state action coverage, ${ }^{201}$ it did not reject the framework for analyzing state involveınent $\mathrm{m}$ private activities established in Burton v. Wilmington Parking Authority ${ }^{202}$ and followed in BEM v. $F C C .{ }^{203}$ "Foster," "encourage," "joint venturer," and "monopoly" are all qualitative terms, of course, that provide no precise measure of what is sufficient state entanglement; nonetheless, it seeins clear that the state's involvement with the broadcasting industry is inuch more elaborate than its imvolvement with liquor hicensees. Although regulatory control over hiquor licensing may parallel regulatory control over

198. 92 S. Ct. 1965 (1972).

199. Id. at 1971.

200. Justice Douglas, dissenting, stressed that club licensees were permitted to serve liquor 17 more hours per week than licensees that served the public thereby giving private clubs monopoly control over liquor service for a certain number of hours each day. Id. at 1976 \& n.3. Justice Douglas also noted that the license quotas, at least in Harrisburg, Pennsylvania, had been full for many years, thereby making it extremely difficult for new clubs to get licenses. Id. at 1976.

201. See Irvis v. Scott, 318 F. Supp. 1246, 1251-52 (M.D. Pa. 1970); Seidenberg v. McSorley's Old Ale House, Inc., 317 F. Supp. 593, 599 (S.D.N.Y. 1970).

202. 365 U.S. 715 (1961).

203. 450 F.2d 642 (D.C. Cir. 1971). 
broadcasters, ${ }^{204}$ the dominance over broadcast speech by radio and television is certainly of a very special character. ${ }^{205}$ Whereas Mr. Irvis could still get a drink at any of a number of public bars, spokesmen for $\mathrm{BEM}$ and political candidates without money who are denied broadcast time simply will not have access to a forum that has the sweeping impact of radio and television. Thus, although Moose Lodge halted expansion of the state entanglement theory of state action introduced in Burton, it did nothing to undercut the basic premise that an elaborate interrelationship between the state and a private entity may still justify constitutional scrutiny of private activities.

\section{c. State Sanction of Private Discrimination}

State action has been found under the state sanction theory in two contexts: (1) where the state is passive and refuses to require a regulated private entity to change policies that racially discriminate or impair free speech;:206 (2) where the state is active and enforces private agreements entailing private discrimination. ${ }^{207}$ In the first imstance, the Court has affirmatively required the state agency to restrain the challenged activity. In the second instance, the Court has simply forbidden state enforcement of the private agreement.

In Moose Lodge, the Court refused to order the Pennsylvania Liquor Control Board to deny Moose Lodge a license thereby rejecting the first state sanction theory. Instead, it employed the second theory and struck down a liquor board regulation that required every club licensee-including Moose Lodge-to "adhere to all the provisions of its constitution and by-laws." 208 The national by-laws of the Moose Lodge restricted membership and guest privileges to Caucasians. ${ }^{209}$ The Court held that the liquor board's regulation, though neutral in its terms, was unconstitutional since its practical effect was to place state sanction behind discrimination by a private club. The Court enjoined enforcement of the regulation, though this was no solace to the plaintiff

204. Justice Brennan quotes the lower court's detailed description of Pennsylvania's regulation of liquor sales in his dissenting opinion to Moose Lodge. $92 \mathrm{~s}$. Ct. 1965, 1978-79 (1972).

205. See note 100 supra and text accompanying notes 176-78 supra.

206. Public Utilities Comm'n v. Pollack, 343 U.S. 451 (1952) (a public utility commission's refusal to order a publicly regulated private bus company to cease playing loud music that interfered with passenger conversation was impermissible state abridgment of free speech).

207. Shelley v. Kraeiner, 334 U.S. 1 (1948) (a court's approval of a racially restrictive covenant in a land sale agreement between private parties is impermissible state action).

208. $92 \mathrm{~S}$. Ct. at 1973 citing Regulations of the Pennsylvania Liquor Control Board \& 113.09 (June 1970 ed.).

209. Id. at 4716,4720 . 
since Moose Lodge was still free to follow its exclusionary by-laws with or without official state approval.

Nevertheless, the holding has significance for political candidates seeking radio and television time. If the FCC approves a station's refusal to grant an indigent candidate free broadcast exposure, it will be relying on its view that section 315 (a) requires that purchased campaign time be matched by an opportunity to purchase comparable time, not by an offer of free time to those who cannot pay. Thus, like the Pennsylvania Liquor Control Board regulation, section 315(a) though neutral on its face, would be discriminatory in application since it impairs the ability of candidates without money to run for political office. Unlike the Moose Lodge regulation, however, if section 315(a) were struck down, the impact would be considerable. Either Congress would have to devise a new and more fair way of regulating campaign advertisenents, or else television and radio stations, within limits of the fairness doctrine, could provide free and purchased time to whomever they wished. Such a result, of course, falls short of requiring broadcasters themselves to conform with equal protection and first amendinent restraints, as the state function and state entwinement theories would do; at a minimum, however, invalidating section 315(a) imight prod legislators into seriously considering alternative methods of handling political broadcast advertising. Some of these options are discussed in the section that follows.

Whichever state action theory is used, ${ }^{210}$ the essence of the test is still to gauge the extent of government entwinement and the public nature of the business enterprise involved. The Suprene Court in Red Lion Broadcasting Co. v. FCC, ${ }^{211}$ though not required to pass upon a state action question, nevertheless discussed in detail the government's involveinent with the broadcasting industry and the public nature of its activities. Despite the Court's apparent intention to limit expansion of state action doctrine, its broad language in Red Lion suggests that it is far from certain that the Court will reverse $B E M$ upon a finding of no state action.

\section{Alternative Means of Financing Campaign Broadcasts}

If, after weighing whether activities by the broadcasting industry constitute discrimination against the poor, whether the broadcasters are

210. In his dissent to the FCC's decision in the BEM case (25 F.C.C.2d 242, 249-64 (1970) ), and in a subsequent article, Johnson \& Westen, supra note 169, at 587-609, FCC Commissioner Nicholas Johnson sets forth no less than eight different theories upon which a finding of state action by the broadcasting industry could be premised. The court in $B E M$ cited his argunents as "strongly" made, though it chose to employ a broader and less analytical approach. $450 \mathrm{~F} .2 \mathrm{~d}$ at $651 \mathrm{n} .16$.

211. 395 U.S. $367,387-90,393-95$ (1969). 
materially abridging the candidate's right to run for office and the right of the candidate's supporters to vote effectively, whether denial of broadcast time abridges the candidate's right of effective speech, and whether state action is involved, a court in fact chooses to apply a strict equal protection standard, the task of ineasuring the strength of the governmental interests and evaluating the availability of less restrictive alternatives remains.

Under Bullock v. Carter, ${ }^{212}$ imposition of the strict equal protection test raises a two-pronged inquiry. First, does the state seek to promote a legitimate interest? Second, are the means chosen to achieve that interest both reasonable and necessary? ${ }^{213}$

One crucial interest that broadcasters have in not giving away advertising time is financial. Arguably, if broadcasters were required to give free time to all candidates or free time to all candidates who could not pay, paid commercial spots for toothpaste and automobiles would have to be cut back, substantially reducing advertising revenue. Or on the other hand, licensees might choose to discontinue cainpaign advertising altogether rather than risk financial harm. In Bullock, the Supreine Court recognized that a state had a legitimate interest in husbanding its resources, ${ }^{214}$ and broadcasters' financial interests may deserve similar recognition. Nevertheless, there is precedent for requiring broadcast licensees to give away free time. The fairness doctrine requires hicensees to provide free time for replies to personal attacks or for responses to inessages treating controversial issues of public importance. ${ }^{215}$ Despite pleas frown the broadcasting industry that this imposes an extreme financial burden, the Supreme Court approved the free time requirement of the fairness doctrine in Red Lion Broadcasting Co. v. FCC. ${ }^{216}$ Moreover, the Court noted that the possibility that hicensees would respond by discontinuing controversial broadcasts was too speculative to warrant pivotal consideration. ${ }^{217}$

Of course, providing free broadcast time to all indigent candidates inay create a heavier financial burden than free reply time under the fairness doctrine, especially if there are many candidates and all requests for time are bunched near election day. Nevertheless, even if

212. 405 U.S. 134 (1972).

213. See note 76 supra and accompanying text.

214. 405 U.S. at 147.

215. Moreover, if a station endorses a political candidate, it must give his opponent a cliance to respond, free of clarge. 47 C.F.R. $\$ \$ 73.123(\mathrm{c}), 73.300$ (c), 73.598(c), 73.679(c) (1971) (identical sections).

216. 395 U.S. at 396.

217. Id. at 393. This may be even more true of political campaign broadcasts since broadcasters will jeopardize their licenses under the new Federal Election Campaign Act if they refuse to provide campaign time for political candidates. Pub. $L$. No. 92-225, 86 Stat. 3 \$ 103 (a)(2) amending 47 U.S.C. $\$ 315$ (a) (1970). 
the financial interests of broadcasters are legitinate, they must still show that denying time to candidates who cannot pay is necessary to protect that interest.

One obvious alternative is for the government to subsidize the cost of candidate air time. Congress has determined that this approach is feasible for presidential elections. ${ }^{218}$ Arguably, it is feasible for all elections. ${ }^{219}$ The major problem would be to limit the number of candidates eligible for such a subsidy to a manageable number, while at the same time avoiding distinctions that impermissibly restrict constitutional rights.

One workable approach may be to allocate broadcast time on the basis of the ability of candidates to reacli at least one of several thresholds-for example, a certam level of voter support for their party in a previous election; or a specified amount of present voter support as reflected by the opinion polls; or, in national elections, whether they appear on the ballot in a requisite number of states; or, finally, whether they are able to gather a reasonable number of signatures on a petition, nuch like the practice approved for ballot eligibility by the Supreme Court in Jenness v. Forston. ${ }^{220}$ Such a multi-threshold approach is similar to one that lias been suggested by the FCC for both national and local elections. ${ }^{221}$ Although it may not be an ideal solution, it

218. See text accompanying notes 127-31 supra.

219. In 1970, Rep. John B. Anderson (R.-Ill.) introduced a bill that would have required stations to set aside blocks of time, to be paid for at the lowest commercial rates by the federal government, for candidates for the Presidency, the Senate, and the House. H.R. 19904, 91st Cong., 2d Sess. §§ 301-307 (1970).

220. 403 U.S. 431 (1971).

221. Under the FCC proposal, if a station sells time to one candidate, it is still obligated to offer to sell comparable time to his opponent, though not obligated to give away free time. If a station gives free time to one candidate in a general election, however, the FCC proposes that section 315(a) be amended so that in presidential and vice-presidential elections, free time must also be given to those candidates (1) who represent a party that appeared on the ballot in at least 34 of the states in the last presidential election and that reccived at least 2 percent of the total vote in that election or (2) who are on the ballot in at least 34 states and who receive petition signatures in all the states equal to at least 1 percent of the total popular votes cast in the preceding presidential election.

Thus, new parties as well as established parties would be entitled to free and equal broadcast time. (Past third party candidates such as Henry Wallace of the Progressive Party in 1948, Strom Thurmond of the Dixiecrats in 1948, and George Wallace of the American Independent Party in 1968, would have qualified as major contenders under these standards.) Moreover, a candidate with only regional support, who does not appear on the bailot in 34 states, would be entitled to free and equal time in those states in which his party received 2 percent of the vote in the previous election. A legally qualified candidate who failed to meet any of the above requirements would be entitled to some broadcast exposure under the fairness doctrine.

The FCC plan also covers candidates for federal, state, and municipal offices. A candidate would be entitled to free and equal time if (1) he is the nominee of a political party that received at least 2 percent of the votes cast for that office in the 
nevertheless meets a test of rationality and avoids drawing constitutionally impermissible lines on the basis of wealth. In order to show that a challenged practice is not necessary to a legitimate state interest, a wiser or more commendable alternative need not be shown; it is sufficient to point to an alternative that is both reasonable and less constitutionally objectionable than the statute under scrutiny. ${ }^{22}$

A question remains, of course, whether such a multi-threshold approach is less restrictive than the way radio and television campaign time is currently apportioned. The suggested method for allocating time, like any regulation of the electoral process, is vulnerable to first amendment challenge on the theory that it would restrict the freedom of political expression of candidates unable to reach one of the established thresholds. There is no magic formula to test which of the two methods for allocating time is less constitutionally offensive. Nonetheless, it would seem that the multi-threshold approach is preferable: a petition demonstrating some degree of political support, for instance, inore closely measures the viability of a candidacy and more equitably regulates candidate access to the voters, than the present method of apportioning time according to ability to pay. In short, it seems more fair to demand signatures than to demand inoney.

It is noteworthy that many countries, including England, West Germany, France, Italy, Japan, and the Scandanavian countries, provide their political candidates free television and radio exposure. ${ }^{223}$ In Great Britain, for example, campaigns are limited to about three weeks duration during which the three television networks make available without charge a certain number of broadcasting periods that the three major parties, Labour, Conservative, and Liberal, divide among themselves. $^{224}$ Any minority party that nominates at least 50 persons for

previous election or (2) his candidacy is supported by petitions that bear a number of signatures equal to at least 1 percent of the total vote cast for that office in the preceding general election. 1970 Hearings, supra note 100 , at 16 (testimony of Dean Burch, FCC Chairman).

222. The Supreme Court has noted:

[I]f there are other, reasonable ways to achieve [a state's] goals with a lesser burden on constitutionally protected activity, a state may not choose the way of greater interference. If it acts at all, it must choose "less drastic means."

Dunn v. Blumstein, 405 U.S. 330, 343 (1972) citing Shelton v. Tucker, 364 U.S. 479, 488 (1960).

223. S. Mickelson, The Electruc MIRROR 252 (1972). In West Germany and Italy all commercials, mcluding campaigns advertisements, are lumped together in a specified time period during the day. In the 1969 Japanese election, the government subsidized all political broadcasts on commercial stations. 1d. at 252-53. See Scott, supra note 134, at 1042-46, for a description of the Canadian and French systems of allocatimg candidate broadcast time. See also Derby, supra note 134, at 302, for a description of the Australian system.

224. Mickelson, supra note 223, at 252. The two government-owned British Broadcasting Company (BBC) networks have no commercials and therefore lose no 
seats in Parliament is given some time, though less than the major parties. $^{225}$ Of course, the British system has been successful partly because campaigns focus on party identification more heavily than do campaigns in the United States. In Britain, party leaders ordinarily decide who will appear on campaign broadcasts and local candidates may get little exposure. ${ }^{226}$ Splinter parties and primary elections create other difficulties. These differences suggest that a more sophisticated system would have to be devised if the English model were adopted in this country. Nevertheless, the electoral systems of the two countries are similar enough to warrant instructive comparison.

Balanced against the candidates' interest in exposure, however, there is arguably a public interest in clear identification of major issues and major candidates. One function of the present method of alloting broadcast time may be to ensure that voters are informed of the major campaign issues and made aware of the major candidates; if minor candidates were given equal exposure, the time allocated to the major candidates would be diluted. This argument assumes, however, that the importance of a candidacy is a function of its economic strength. Thus, though the mterest in liaving major issues and candidates publicized is important, allocating broadcast time on the basis of ability to pay is an imprecise way of achieving it. Indeed, this interest is little different from the desire to exclude frivolous candidates from the ballot that was pressed in Bullock and which the Court found to be served in an impermissibly imprecise fashion by a filing fee requirement. $^{227}$

If a court declared the equal opportunities provision of section 315(a) unconstitutional, the resulting situation might be one in which stations could not charge any candidate for advertising time, could only charge those able to pay, or could, within restraints of the fairness doctrine, provide time to whomever they wished. This Cominent does not suggest that such a result would be markedly better than the exist-

revenue by providing free campaign time. The Independent Television Authority (ITA), on the other hand, is a public corporation that loses advertising revenue when it must preempt sponsored programs in favor of political advertising. Id.

225. British Broaddasting CoRP., BBC HandBooK 196469 (1963). The three major parties in Great Britain receive an allocation of free radio and television time throughout the year on the basis of their showing at the most recent general and byelection. Id. at 66-67. Candidates for both Parliament and local offices must operato within strict spending limitations. For example, candidates for House of Cominons from rural districts may spend no more than $£ 750$ plus one shilling for exery six voters in the district; candidates from urbau districts may spend no more than $£ 750$ plus one shilling for every eight voters in the district. Represeutation of the People Act of 1969, c. 15, $\$ 8(1)$ (a), amending Representation of the People Act of 1949, 12, $13 \& 14$ Geo. 6, c. $68, \$ 64(1)$.

226. Mickelson, supra note 223, at 263-64.

227. 405 U.S. 134,146 (1972). 
ing practice. The use of television in political campaigns would still fall short of being an unbiased and unglamorized chronicler of information the voting public should have before making voting decisions. Nevertheless, froin a practical point of view, a situation in whicl every legally authorized candidate or else every indigent candidate gets free and equal time, or a situation in which broadcasters may provide time to whomever they cliose, may prod legislators to involve government inore extensively in the financing of political campaigns, on both the national and local levels. Though campaign reform is currently in vogue, it is slow and piecemeal. It might cynically be said that legislators are not anxious to nake the airwaves more accessible to all candidates since it is not the rich, powerful, and influential who are hurt by the present system. On the other hand, in a judicially mandated system of free time for everyone, it is the rich, powerful, and influential who would be liurt the most and who would be anxious to urge legislators to act. ${ }^{228}$

The Federal Election Campaign Act of 1971, which establishes ceilings for inedia expenditures, is a commendable reform. Its ceilings are far from overrestrictive, however, and less wealthy candidates reinam seriously disadvantaged. Moreover, any dollar limitation is difficult to enforce and tends to encourage surreptitious inoney transactions. Government subsidies, on the other hand, would promote inore equal access to the political arena and would displace the corrupting influence of private campaigu financing.

After the Federal Election Campaign Act was reported out of committee, Senator Hart (Dem.-Mich.) noted:

[This bill] will move campaign expenditure reform a long way on the road to giving all federal candidates equal access to the media and removing an mequality which grows larger with each succeeding election.

228. It is not at all uncommon for courts to declare a statute or a state practice unconstitutional and leave a void that a legislature or administrative agency is obligated to fill. The decision in $B E M$, for example, simply stated that broadcasters could no longer refuse controversial advertisements as a matter of policy. The court gave no guidelines, however, on how access would be administered consistent with the fairness doctrine. It is incumbent upon either Congress or the FCC to resolve that dilemma. The series of recent cases that have declared state reliance on property taxes for school financing to be violative of the equal protection clause have siunilarly made it incumbent on the legislative branch to devise a less constitutionally objectionable financing plan. Rodriguez v. San Antonio Independent Scliool Dist., 337 F. Supp. 280 (W.D. Tex. 1971) prob. juris. noted, 92 S. Ct. 2413 (1972); Dusartz v. Hatfield, 334 F. Supp. 870 (D. Minn. 1971); Serrano v. Priest, 5 Cal. 3d 584, 487 P.2d 1241, 96 Cal. Rptr. 601 (1971); Robinson v. Cahill, 118 N.J. Super. 223, 287 A.2d 187 (Law Div. 1972), opinion supplemented, 119 N.J. Super. 40, 289 A.2d 569 (Law Div. 1972). 
But if we are really to neutralize the power of money to distort the election process; if public office is to be within the reach of not the rich alone; if we are to eliminate the influence, real or imagined, of the large contributor; if we are to remove the cynicism with which young and old alike view today's fund raising efforts by political parties and candidates; if we are to make our political campaigns a testing ground for ideas and issues rather than exercises for our money-raisers-then I believe we must eliminate our dependence on private contributions. ${ }^{22 \theta}$

\section{III}

\section{CANDIDAte Newspaper AdVertising}

Political candidates without funds are not only barred from advertising on radio and television; they are also unable to buy advertising in the printed media. Newspaper advertising may not generally be as significant a factor in most elections as radio and television advertising, ${ }^{230}$ but candidates still spend a great deal of money on it. In 1968, for example, candidates on all levels across the country spent $\$ 11.6$ million on newspaper advertising, a 50 percent increase over the amount candidates spent im $1964 .{ }^{231}$ In the 1971 San Francisco municipal election, four of the mayoralty candidates spent over $\$ 100,000$ on newspaper advertising..$^{232}$ The 33 candidates for seats on the Board of Supervisors spent more than $\$ 25,000$ on newspaper advertising with over 70 percent of that amount being expended by the six winners. ${ }^{233}$ Like inaccessibility to radio and television, inaccessibility to newspaper advertising can impair a candidate's abihty to communicate his views to potential voters and weaken the effectiveness of his campaign. Moreover, if a newspaper, like a radio or television station, sells space to candidates who can afford to pay and denies space to candidates who cannot pay, it is discriminating against the poor. Again, a central question is whether or not denial of newspaper space is state action.

229. U.S. Code Cong. and Ad. News, No. 1, 92d Cong., $2 d$ Sess., at $73-74$ (1972).

230. It is likely that in soine elections newspaper advertising is more important than broadcast advertising. For example, a Congressional district in Ncw Jersey may be served by television stations that also serve New York City; thcreforc, advertising would be both expensive and incfficient. In such a situation, local newspaper advertising would be a much wiser campaign expenditure.

231. H. ALEXANDER, supra note 98 , at 111 . In 1964 candidates spent $\$ 7.74$ million; in 1956, $\$ 4.28$ million. Id.

232. Joseph Alioto, $\$ 23,366.08$; Diane Feinstein, $\$ 14,253.80$; Scott Newhall, $\$ 62,431.34$; Harold Dobbs, $\$ 424.00$. Candidate spending reports on file with the Registrar of Voters, City and County of San Francisco.

233. Id. The spending statistics for the six winners are: Ron Pelosi, \$2,803.00; Terry Francois, \$2,919.70; Robert Mendelsohn, \$5,894.63; Quentin Kopp, \$2,474.34; Robert Gonzales, $\$ 3,144.30$; John Molinari, $\$ 362.50$. 
Three recent cases have dealt with this issue, ${ }^{234}$ and each concluded that the activities of a newspaper do not constitute state action. Each case involved a claim that denial of paid advertising space violated the first amendinent. In Chicago Joint Board, Amalgamated Clothing Workers v. Chicago Tribune Co., ${ }^{235}$ a labor union sought to purchase advertising space in Chicago newspapers as part of a campaign to limit the importation of foreign-1nade clothing. The newspapers rejected the advertisements on the ground that they failed to conform to the newspapers' guidelines, which allowed the newspapers to reject an advertisenient that "reflects unfavorably on competitive organizations, institutions or merchandise" or is "misleading."236 The newspapers also reserved the right "to reject any advertising which in its opinion is unacceptable." ${ }^{237}$ In the second case, Associates \& Aldrich Company v. Times Mirror $\mathrm{Co}^{238}{ }^{238}$ a movie producer clained that a newspaper's refusal to carry a niovie advertisement violated the first amendment. Last, Resident Participation of Denver, Inc. v. Love ${ }^{239}$ concerned a newspaper's refusal to carry an advertisement on behalf of a group objecting to construction of a plant to cut up animal carcasses. Each case dismissed the coinplaint on a finding of no state action.

Complamants in each case argued that the state was closely involved with the newspapers by virtue of several state statutes affording the newspapers certam benefits. For example, there were statutes exempting newspaper einployees from jury service, requiring newspaper publication of certam legal notices for which the newspaper was compensated, and providing vending machine space on public streets. In addition, the newspapers were commonly given press roouns in public buildings. ${ }^{240}$ Coinplaimants also argued that the newspapers enjoyed a nnonopolistic position and thus were essentially carrying out a state function of administering all printed communication within a locality. ${ }^{241}$

Each court concluded that the state was not sufficiently involved in the newspapers' activities to raise it to the level of joint participant as required by the Supreme Court's opinion in Burton $v$. Wilmington

234. Associates \& Aldrich Co. v. Times Mirror Co., 440 F.2d 133 (9th Cir. 1971); Joint Bd., Amalg. Clothing Workers v. Chicago Tribune Co., 435 F.2d 470 (7th Cir. 1970), cert. denied, 402 U.S. 973 (1971); Resident Participation, Inc. v. Love, 322 F. Supp. 1100 (D. Colo. 1971).

235. 435 F.2d 470 (7th Cir. 1970).

236. Id. at 473 n.2.

237. Id.

238. 440 F.2d 133 (9th Cir. 1971).

239. 322 F. Supp. 1100 (D. Colo. 1971).

240. Joint Bd., Amalg. Clothing Workers v. Chicago Tribune Co., 435 F.2d at 473.

241. Resident Participation Inc. v. Love, 322 F. Supp. at 1104. 
Parking Authority, ${ }^{242}$ and that, in any event, the traditional role of the press has always been one of healthy disassociation from the state. ${ }^{243}$

It is no doubt true that the state's involvement with the newspaper industry is less intimate than its mvolvement with the broadcasting industry. Newspapers are not licensed by the state and they do not enjoy the use of a government-owned limited-access medium as do broadcasters. Nevertheless there are several factors to suggest that it is illogical to treat the newspaper industry different from the broadcasting industry when considering the constraints of the equal protection clause and the first amendment.

One important consideration is that in any given city one newspaper company usually dominates the printed cominunication much more pervasively than does one television station. Most cities have several television stations, but often they have only one newspaper or two newspapers owned by the same publisher. ${ }^{244}$ In fact, of the more than 1,500 American cities with daily newspapers today, over 1,450 of them, or 97 percent, are served by some sort of daily-newspaper monopoly. ${ }^{245}$

The significance of the limited number of newspapers in the country is that a person seeking advertising space may be totally barred from cominumicating his ideas in print if the only newspaper in town refuses to sell him space. Such a situation is remarkably similar to others in which the courts have concluded that a private enterprise is carrying on a governmental function. In Marsh v. Alabama, ${ }^{240}$ for instance, the Supreine Court held that abridgment of free speech by a company town that had assumed the roles and obligations of a public municipality was impermissible state action under the first amendment. In Amalgamated Food Employees Union v. Logan Valley Plaza ${ }^{247}$ the Court held that the passageways of a privately owned shopping center were of such a public nature that persons had the same first amendment right to picket there that they had along a downtown street. In both cases, the Court reasoned that the private enterprise was essen-

242. 365 U.S. 715 (1961); see note 179 supra.

243. See Joint Bd., Amalg. Clothing Workers v. Chicago Tribune Co., 435 F. $2 \mathrm{~d}$ at 474.

244. In 1970, there were 1,700 English language newspapers in the country while there were 6,902 television and radio stations. There were 672 television stations, 4,209 A.M. radio stations and 2,021 F.M. radio stations. NEwSPAPER ENTERPRISB Assoc., INC., 1972 WordD ALManac 144, 338 (1971).

245. Of 1,511 cities with daily newspapers, 1,304 have only one daily; 141 have two dailies under joint ownership; and 21 have two dailies separately owned but pub. lished under a joint-operating agreement that eliminates economic competition. EDIror \& PUblisher, July 17,1971 , at 7.

246. 326 U.S. 501 (1946).

247. 391 U.S. 308 (1968). 
tially carrying out a state function and thus would have to abide by the same constitutional restraints as the state.

Newspapers present a different situation froin Logan Valley and Marsh, of course, since the government has never been in the business of publishing a newspaper; nevertheless, rapid and reliable printed communication is so fundamental a governmental interest that it is certainly arguable that newspapers serve a state function. ${ }^{248}$ This is even more the case when one newspaper monopolizes the print in an entire geographical area and thereby assumes a dangerous power over the flow of community ideas and the direction of public opinion.

Of course, as has been noted, ${ }^{249}$ the Supreme Court's recent decision in Lloyd Corp. v. Tanner ${ }^{250}$ significantly narrowed Marsh and Logan Valley and suggests that the Court will employ the governmental function theory of state action in only very limited circumstances. Despite arguments to the contrary, it is doubtful whether newspapers fall within those limitations.

Another aspect of Logan Valley, ignored in Lloyd, but in any event analogous to an analysis of the newspaper industry, is the Supreme Court's recognition of the importance of conforming state action theory to changing social patterns. The Court noted in Logan Valley that the movement of the population from the public streets of the cities to privately owned shopping centers in the suburbs liad resulted in a contraction of available public forums for first amendment speech. ${ }^{251}$ Therefore, it concluded that the notion of public forums must be expanded to include the premises of a privately owned suburban shopping center. ${ }^{252}$ Similarly, the steadily decreasing number of newspapers in this country ${ }^{253}$ has contracted the number of forums for exercising first anendment rights in the printed media. The domination of monopoly newspapers today makes total exclusion froin printed first ainendment speech a real possibility. This development, similar to the demographic shift noted in Logan Valley, may therefore make it important to expand state action doctrine to remedy the deleterious effect of this particular sort of social clange on the availability of first amendinent forums.

248. See Barron, Access to the Press-A New First Amendment Right, 80 HARV. L. Rev. 1641, 1669 (1967).

249. See text accompanying notes 188-97 supra.

250. 92 S. Ct. 2219 (1972).

251. 391 U.S. at 324.

252. Acknowledging the majority's failure to raise this issue in Lloyd, Justice Marshall, dissenting in Lloyd, asserted that it was as applicable to Lloyd Center as to Logan Valley Plaza. 92 S. Ct. 2219, at 2230-31.

253. Between 1910 aud 1971 , the number of cities with competing daily uewspapers declined from 689 to only 45 . The number of cities with non-competing dailies increased from 518 to 1,466. See note 245 supra and J. Wiggrns, FreEdom OR SECRECY 178 (Rev. ed. 1964). 
A stronger argument is that newspaper state action arises from an entwinement between the newspaper imdustry and the government. In addition to the sundry state-conferred benefits enjoyed by newspapers, such as exemption of employees from jury duty and access to vending machines on public streets, monopoly newspapers also enjoy antitrust exemption by virtue of the Newspaper Preservation Act. ${ }^{254}$ That Act permits newspapers to merge if one is in danger of failing. Although they must maintain separate editorial and reporting staffs, they may have joint advertising departments. Thus, if an indigent candidate is refused advertising space by one newspaper, by virtue of government sanction there may be no competing newspaper to which he can turn. Moreover, the antitrust exemptions of the Newspaper Preservation Act constitute a government conferred privilege strikingly similar to the exclusive license privileges enjoyed by broadcasters. Not only does this markedly increase the government's involvement with newspapers that take advantage of the Act, but more significantly, it makes the government a "joint participant" in their efforts to maintain financial stability. This may be as significant a case of government entwinement as the relationship between the restaurant and the parking authority in Burton v. Wilmington Parking Authority ${ }^{255}$ which the Supreme Court labeled "state action."

There is a final anomaly that emphasizes the illogic of treating broadcasting stations and newspapers differently for state action purposes. In New York Times v. Sullivan ${ }^{256}$ and Rosenbloom v. Metromedia, Inc. ${ }^{267}$ the Supreme Court held that both newspapers and broadcasters may only be held responsible for libel against a public officer or a person involved in an event of public or general concern if they are guilty of knowingly or recklessly publishing falsehoods. ${ }^{208}$ One justification for this standard is that public officials and public figures have a certain amount of access to the mass media and thus should be able to defend themselves publicly. ${ }^{269}$ This may be partly true with regard to radio and television since the fairness doctrine provides free reply time to victims of broadcasted "personal attacks."260 Absent a state statute, however, there is no comparable right of reply in the pages of a newspaper. ${ }^{261}$ It would seem that if the same stand-

254. 15 U.S.C. $\$ \$ 1801-04$ (1970).

255. 365 U.S. 715 (1961); see note 179 supra.

256. 376 U.S. 254 (1964).

257. 403 U.S. 29 (1971).

258. 403 U.S. at $52 ; 376$ U.S. at $279-80$.

259. 403 U.S. at $45-47$.

260. See Red Lion Broadcasting Co. v. FCC, 395 U.S. 367 (1969).

261. A handful of states have right to reply statutes. See, e.g., Miss. CoDs ANN. $\$ 3175$ (1942) (political candidates have right to reply, free of charge, to "any editorial or news story reflecting upon their honesty or integrity or moral char- 
ards for libel are employed for newspapers and broadcasters, the same standards for right of access to reply might also apply.

Sucl a comparison, of course, provides, at best, peripheral support for the argument that the way newspapers liandle political advertising is state action. ${ }^{262}$ Nonetheless, it underscores the notion that the broadcast and newspaper industry's influence over the flow of information today may be so similar that it is illogical not to require them to conform to the same first amendment and equal protection standards. Indeed, from an administrative poimt of view, newspapers would probably be able to handle free or government-subsidized campaign advertising witl much greater ease than broadcasters. While radio and television stations have strict time limitations over how much they can broadcast in a day, newspapers may simply add extra pages to their press runs thereby accommodating a large number of political advertisers at less cost and inconvenience than broadcasters would have to bear to provide similar exposure.

\section{CONCLUSION}

The spiraling cost of campaigning for elective office is one of the most disturbing features of this country's political system. Congress has taken tentative steps to solve this problem by creating a taxpayerfinanced fund for presidential elections, beginning in 1976, and by setting spending ceilings for all federal elections. However, the controls chosen raise serious constitutional questions. Moreover, the ceilings are not very stringent; state and local elections remain largely unregulated; and all candidates, except for presidential nominees, must still depend heavily on private financing to mount effective campaigns.

The Supreme Court's recent decision in Bullock v. Carter, which struck down candidate filing fees for violating equal protection, provides cornerstone support for an attack on the unavailability of broadcast advertising time and newspaper space for indigent political candidates. For, like the filing fee in Bullock, which denied plaintiffs the right to run in a primary election where their campaigns would be most effective, a denial of broadcast and newspaper advertising also prevents indigent candidates from running for office in an effective manner. Recent cases positing a right of access to the electromic media under the first amendment support this position.

acter. . . ."); WIS. STA9. § 895.05(2) (1966) (if true facts are unascertainable, publication of libelled individual's version of the facts will mitigate damages).

262. A somewhat attenuated argument may be made that finding a constitutionally required right to reply to a personal attack in a newspaper necessitates a finding of newspaper state action, thereby suggesting that newspapers should also be deemed state action when the problems of political advertising are considered. 
A comprehensive legislative scheme aimed at providing government subsidies for all political campaigns on all levels would be the most effective means of completely removing the corrupting influence of private money from politics. One solution to the difficult problem of determining standards of eligibility for the government subsidy may be to grant broadcast time and newspaper space to those candidates who represent a party that received a certam percentage of the vote in the previous election, who received a certain thresliold support in opinion polls, or who are able to gatler a certain number of voter signatures to indicate an acceptable level of support.

In the absence of legislative initiative to remedy this problem, however, it is nevertheless within the provimce of the judiciary to declare the present system by which broadcast time and newspaper space is allocated-that is, on the basis of ability to pay-to be unconstitutional and thus cast upon the legislative branch the immediate burden of devising a just and equitable substitute.

Michael J. Baker

\section{APPENDIX}

\begin{tabular}{|c|c|c|c|c|}
\hline State & $\begin{array}{l}\text { Projected } 1972 \\
\text { Voting Age } \\
\text { Population }\end{array}$ & $\begin{array}{c}1972 \\
\text { Ceiling** }\end{array}$ & 1970 Expenditures & 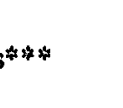 \\
\hline Alaska & $-\quad 193,000$ & $\$ 31,290$ & Kay ___ & $\$ 34,000$ \\
\hline Arizona & $-1,227,000$ & 74,408 & $\begin{array}{l}\text { Stevens (W) } \\
\text { Grossman }\end{array}$ & $\begin{array}{l}17,300 \\
85,400 \\
84,300\end{array}$ \\
\hline California _- & $-14,237,000$ & 850,212 & $\begin{array}{l}\text { Tunney (W) } \\
\text { Murphy }\end{array}$ & $\begin{array}{l}466,700 \\
385,700\end{array}$ \\
\hline Connecticut & $2,117,000$ & 128,665 & $\begin{array}{l}\text { Duffey } \\
\text { Weicker (W) }\end{array}$ & $\begin{array}{l}87,000 \\
81,400 \\
49,600\end{array}$ \\
\hline Delaware & 372,000 & 31,290 & $\begin{array}{l}\text { Zimmerman } \\
\text { Roth (W) }\end{array}$ & $\begin{array}{l}12,300 \\
13,600\end{array}$ \\
\hline Florida & $-5,088,000$ & 306,079 & $\begin{array}{l}\text { Chiles (W) } \\
\text { Cramer }\end{array}$ & $\begin{array}{r}53,900 \\
140,500\end{array}$ \\
\hline Hawaii & 528,000 & 32,041 & $\begin{array}{l}\text { Heftel } \\
\text { Fong (W) }\end{array}$ & $\begin{array}{l}64,900 \\
37,100\end{array}$ \\
\hline Illinois & $7,563,000$ & 463,906 & $\begin{array}{l}\text { Stevenson (W) } \\
\text { Smith }\end{array}$ & $\begin{array}{l}254,900 \\
235,900\end{array}$ \\
\hline Indiana & $3,487,000$ & 214,837 & Hartke (W) & $\begin{array}{l}182,700 \\
353,000\end{array}$ \\
\hline Maine & 662,000 & 41,365 & Muskie (W) & $\begin{array}{r}30,800 \\
8.500\end{array}$ \\
\hline Maryland _ & $-2,715,000$ & 163,334 & Tydings & $\begin{array}{r}92,600 \\
115,900\end{array}$ \\
\hline Massachusetts & - 3,947,000 & 242,998 & $\begin{array}{l}\text { Kennedy (W) } \\
\text { Spaulding }\end{array}$ & $\begin{array}{r}151,500 \\
14,900\end{array}$ \\
\hline Michigan . & $-5,875,000$ & 359,835 & $\begin{array}{l}\text { Hart (W) } \\
\text { Romney }\end{array}$ & $\begin{array}{r}140,700 \\
45,000\end{array}$ \\
\hline Minnesota & $-2,523,000$ & 156,012 & $\begin{array}{l}\text { Humphrey }(W) \\
\text { MacGregor }\end{array}$ & $\begin{array}{l}158,000 \\
166,800\end{array}$ \\
\hline Missou & - 3,222,000 & 199,818 & $\begin{array}{l}\text { Symington (W) } \\
\text { Danforth }\end{array}$ & $\begin{array}{l}192,200 \\
231,500\end{array}$ \\
\hline
\end{tabular}




\begin{tabular}{|c|c|c|c|c|}
\hline & 452,000 & 31,290 & Mansfield (W) _ & 10,600 \\
\hline Nebraska & $1,002,000$ & 62,768 & Morrison & 21,600 \\
\hline evada & 356,000 & 31,290 & $\begin{array}{l}\text { Hruska (W) } \\
\text { Cannon (W) }\end{array}$ & $\begin{array}{l}26,500 \\
68,100\end{array}$ \\
\hline New Jersey & $5,018,000$ & 306,580 & $\begin{array}{l}\text { Raggio } \\
\text { Williams (W) } \\
\text { Gross }\end{array}$ & $\begin{array}{r}73,800 \\
179,900 \\
391,500\end{array}$ \\
\hline New Mexico & 633,000 & 39,238 & $\begin{array}{l}\text { Montoya (W) } \\
\text { Carter }\end{array}$ & $\begin{array}{r}35,400 \\
27,600\end{array}$ \\
\hline New York & $12,714,000$ & 786,193 & Ottinger - & $\begin{array}{l}648,000 \\
570,000 \\
522,000\end{array}$ \\
\hline North Dakota & 398,000 & 31,290 & $\begin{array}{l}\text { Burdick (W) - } \\
\text { Kleppe }\end{array}$ & $\begin{array}{r}44,800 \\
71,500\end{array}$ \\
\hline Ohio _ & $7,165,000$ & 441,314 & $\begin{array}{l}\text { Metzenbaum } \\
\text { Taft (W) }\end{array}$ & $\begin{array}{l}238,500 \\
220,500\end{array}$ \\
\hline Pennsylvania _... & $8,136,000$ & 504,708 & $\begin{array}{l}\text { Sesier } \\
\text { Scott }(\mathrm{W})\end{array}$ & $\begin{array}{r}25,000 \\
268,600\end{array}$ \\
\hline Rhode Island & 671,000 & 41,303 & $\begin{array}{l}\text { Pastore (W) } \\
\text { McLaughlim }\end{array}$ & $\begin{array}{r}16,400 \\
3,300\end{array}$ \\
\hline Tennessee & $2,710,000$ & 166,963 & $\begin{array}{l}\text { Gore } \\
\text { Brock (W) } \\
\text { Bentsen (W) }\end{array}$ & $\begin{array}{l}145,600 \\
173,400 \\
174,700\end{array}$ \\
\hline Utah $\ldots$ & 674,000 & $\begin{array}{r}465,220 \\
41,803\end{array}$ & $\begin{array}{l}\text { Bush } \\
\text { Moss (W) } \\
\text { Burton }\end{array}$ & $\begin{array}{r}292,700 \\
115,300 \\
91,400\end{array}$ \\
\hline Vermont & 301,000 & 31,290 & $\begin{array}{l}\text { Hoff } \\
\text { Prouty }(\mathrm{W})\end{array}$ & $\begin{array}{l}69,700 \\
53,600\end{array}$ \\
\hline irginia & $3,232,000$ & 195,625 & $\begin{array}{l}\text { Rawlings } \\
\text { H. Byrd }(\mathrm{W}) \\
\text { Garland }\end{array}$ & $\begin{array}{l}26,200 \\
97,900 \\
31,400\end{array}$ \\
\hline West Virginia & $1,175,000$ & 74,220 & $\begin{array}{l}\text { R. Byrd }(W) \\
\text { Dodson }\end{array}$ & $\begin{array}{r}8,100 \\
1,900\end{array}$ \\
\hline Wisconsin & $2,948,000$ & 181,106 & $\begin{array}{l}\text { Proxmire (W) } \\
\text { Erickson }\end{array}$ & $\begin{array}{l}41,100 \\
14,300\end{array}$ \\
\hline Vyoming - & 217,000 & 31,290 & $\begin{array}{l}\text { McGee (W) } \\
\text { Wold }\end{array}$ & $\begin{array}{l}47,600 \\
38,700\end{array}$ \\
\hline
\end{tabular}

* Newspaper ENterprise Assoc., INC., 1972 World Almanac 155 (1971).

$\approx \rightarrow$ The greater of 1972 voting age population times 6 cents and $\$ 30,000$ adjusted upwards by percentage increase in cost-of-living index. BROAdCASTiNG, Apr. 24, 1972 , at 22.

$* *:$ N.Y. Times, May 12, 1971, at 20, col. 7.

(W) denotes the winner of each clection. 